\title{
Effects of fatty acids and dietary lipids on cells of the immune system
}

\author{
BY PHILIP C. CALDER \\ Department of Biochemistry, University of Oxford, South Parks Road, Oxford OX1 $3 Q U$
}

\section{Effets des acides gras et des lipides de l'alimentation sur les cellules du système immunitaire}

\begin{abstract}
RÉSUMÉ
La synthèse des acides gras de novo fournit de l'acide palmitique. Celui-ci peut être allongé jusqu'à l'acide stéarique, un substrat de $\mathrm{Pa} \Delta^{9}$-désaturase, donnant ainsi de l'acide oléique $(18: 1 n-9)$. Les animaux ne possèdent pas les enzymes $\Delta^{12}$ ou $\Delta^{15}$ désaturase qui produisent les acides linoléic (18:2n-6) et $\alpha$-linoléique $(18: 3 n-3)$ respectivement; ces enzymes se trouvent dans des plantes qui contiennent donc des proportions élevées d'acides gras polyinsaturés $n-6$ et/ou $n-3$ (AGPI). Etant donné que ces acides gras son nécessaires pour la structure et la fonction de la membrane, elles doivent être consommées dans le régime des animaux, et sont donc appelées acides gras essentiels. Aussi bien les animaux que les plantes possèdent les enzymes pour allonger et désaturer les acides désaturés palmitique, oléique, linoléique et $\alpha$-linolénique. Il résulte des actions de ces enzymes que quatre familles distinctes de AGPI existent $(n-7, n-9, n-6$ et $n-3)$. Les acides gras agissent comme substrats énergétiques et comme constituants de la membrane. Les acides dihomo- $\gamma$-linoléique, arachidonique et éicosapentaénoique sont des précurseurs des éicosanoides et les acides myristique et palmitique peuvent être attachés à certaines protéines de façon covalente. De plus, certains acides gras insaturés agissent comme des messagers intracellulaires seconds. Les éicosanoides sont des régulateurs importants du développement et des fonctions des lymphocytes $\mathrm{T}$ et $\mathrm{B}$, des cellules NK et des macrophages. Dans les conditions normales, la plupart des éicosanoides sont dérivés de l'acide arachidonique. Cependant, lorsque des niveaux élevés de AGPI $n-3$ sont consommés dans l'alimentation, il se produit moins d'éicosanoides dérivés de l'acide arachidonique. A la place, des éicosanoides sont formés à partir d'acide éicosapentaénoique. Ceci peut être avoir une signification fonctionnelle, étant donné que les éicosanoides produits à partir d'acide éicosapentaénoique sont d'habitude moins puissants biologiquement que ceux formés à partir d'acide arachidonique. Les acides gras insaturés inhibent un certain nombre de fonctions immune de la cellule in vitro, y compris la prolifération des lymphocytes $\mathrm{T}$ et $\mathrm{B}$ et la cytotoxicité médiée par les cellules NK et $T$ cytotoxique, et la production de cytokines par des lymphoctyes et des macrophages. L'acide éicosapentaénoique semble être le plus puissant inhibiteur de ces activités, bien que d'autres AGPI $n-3$ et AGPI $n-6$ soient aussi des inhibiteurs. Ces effets des AGPI semblent être indépendants des éicosanoides. L'inclusion de AGPI $n-3$ contenant des huiles des l'alimentation d'animaux de laboratoire ou de l'homme résulte dans la suppression de la prolifération des lymphocytes $\mathrm{T}$ et $\mathrm{B}$, de l'activité des cellules NK et de la production de cytokines dérivées de cellules $T$, toutes testées par la suite in vitro. Les régimes riches en AGPI $n$ - 6 (acide soit linoléique, soit $\gamma$-linolénique), ou en acides gras monoinsaturés $n-9$ affectent également les fonctions lymphocytaires; une
\end{abstract}


suppression ex vivo de la prolifération lymphocytaire et des activités cytotoxiques ont souvent été observées. Les résultats d'études de manipulations diététiques de ce genre sur la production $e x$ vivo de cytokines dérivés de macrophages sont moins clairs, avec un certain nombre de résultats contradictoires qui ont été reportés. Ainsi, il apparaît que les lipides de l'alimentation peuvent exercer des effets immuno-modulateurs.

\section{UNSATURATED FATTY ACID SYNTHESIS AND THE FAMILIES OF UNSATURATED FATTY ACIDS}

All mammals can synthesize fatty acids de novo from acetyl-CoA. The endproduct of the fatty acid synthetase ( $E C 2.3 .1 .85$ ) enzyme is palmitic acid (16:0), which may, in turn, be elongated to stearic acid (18:0). There is little need for the synthesis of saturated fatty acids in Western man, since the diet normally supplies adequate amounts. However, cell membranes require unsaturated fatty acids to be provided to maintain their structure, fluidity and function. Therefore, a mechanism for the introduction of double bonds (desaturation) exists. The introduction of a single double bond between C-9 and C-10 is catalysed by the enzyme $\Delta^{9}$-desaturase, which is universally present in both plants and animals. This enzyme results in the conversion of stearic acid to oleic acid (18:1n-9). Plants, unlike animals, can insert additional double bonds into oleic acid between the existing double bond at the C-9 position and the methyl terminus of the $\mathrm{C}$ chain; a $\Delta^{12}$-desaturase converts oleic acid into linoleic acid $(18: 2 n-6)$, while a $\Delta^{15}$-desaturase converts linoleic acid into $\alpha$-linolenic acid (18:3n-3). Many marine plants, especially the unicellular algae in phytoplankton, also carry out chain elongation and further desaturation of $\alpha$-linolenic acid to yield $n-3$ polyunsaturated fatty acids (PUFA) with twenty and twenty-two $\mathrm{C}$ atoms and five or six double bonds. It is the formation of these long-chain $n-3$ PUFA by marine algae and their transfer through the food chain to fish, that accounts for the abundance of eicosapentaenoic and docosahexaenoic acids $(20: 5 n-3$ and 22:6n-3 respectively) in marine fish oils. Animal cells can also convert $\alpha$-linolenic acid to eicosapentaenoic and docosahexaenoic acids; by a similar series of reactions linoleic acid is converted via $\gamma$-linolenic $(18: 3 n-6)$ and dihomo- $\gamma$-linolenic $(20: 3 n-6)$ acids to arachidonic acid (20:4n-6; Fig. 1). As a result of the actions of the $\Delta^{9}-, \Delta^{12}$ and $\Delta^{15}$-desaturase enzymes, four families of unsaturated fatty acids exist; these are the $n-7$, $n-9, n-6$ and $n-3$ families (Fig. 1); these fatty acid families are not metabolically interconvertible in mammals.

\section{HOW MIGHT FATTY ACIDS AFFECT THE FUNCTIONS OF CELLS OF THE IMMUNE SYSTEM?}

Fatty acids have many diverse functions in cells; their principal roles are as energy sources and as membrane constituents. Changing the proportions of different types of fatty acids in cell membranes may alter the fluidity of those membranes. Both the fatty acid composition of plasma-membrane phospholipids and the fluidity of the plasma membrane are known to affect membrane activities, such as ion and substrate transport, receptor functioning and the activities of membrane-bound enzymes (for review, see Brenner, 1984; Stubbs \& Smith, 1984). In addition, some membrane phospholipids, e.g. 

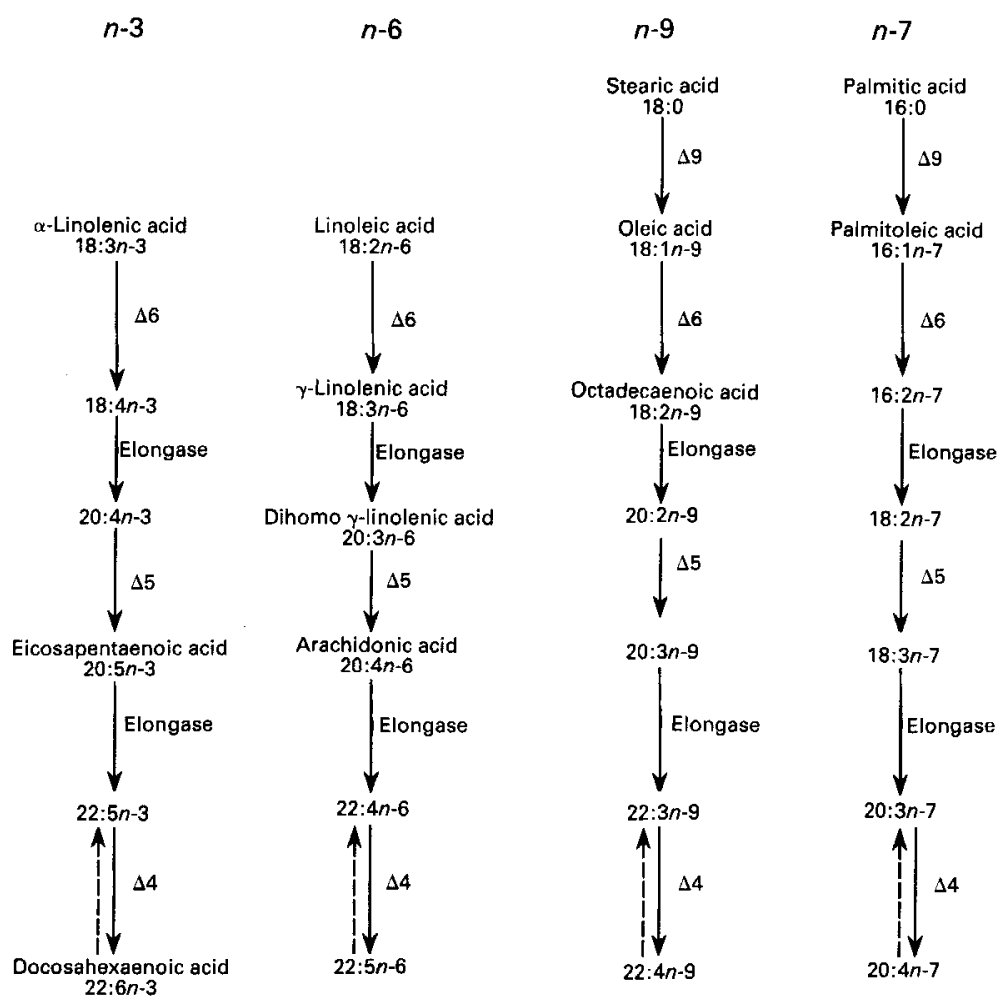

Fig. 1. Pathways for the biosynthesis of polyunsaturated fatty acids.

phosphatidylinositol-4,5-bisphosphate and phosphatidylcholine, are involved in intracellular signalling mechanisms since they act as precursors for second messengers such as inositol-1,4,5-trisphosphate and diacylglycerol. Thus, changing the fatty acid composition of these phospholipids could affect signal transduction processes by altering their ability to act as substrates for phospholipases or by altering the action of the diacylglycerol released. Certain membrane fatty acids have specific roles in the regulation of cell functions. For example, arachidonic, dihomo- $\gamma$-linolenic and eicosapentaenoic acids act as precursors for the synthesis of eicosanoids, an important group of immunoregulatory molecules (see p. 130). The saturated fatty acids, myristic and palmitic, may be covalently attached to certain proteins and this is believed to play an important role in the functioning of these proteins, which are often involved in intracellular signalling pathways (for review, see Towler et al. 1988; Schmidt, 1989; McIlhinney, 1990). Finally, certain fatty acids may have roles as intracellular second messengers; for example, there is evidence that oleic and arachidonic acids, and perhaps other unsaturated fatty acids as well, released by the action of lipases can directly affect the activities of enzymes such as phospholipase $\mathrm{A}_{2}$ and protein kinase $C$ (for review, see Sumida et al. 1993). Since changing the type of fatty acids available to cells, such as lymphocytes or macrophages, results in alteration in the fatty acid composition of the membrane phospholipids of those cells (see p. 134), it is apparent that a change in cell function might follow (Fig. 2). 


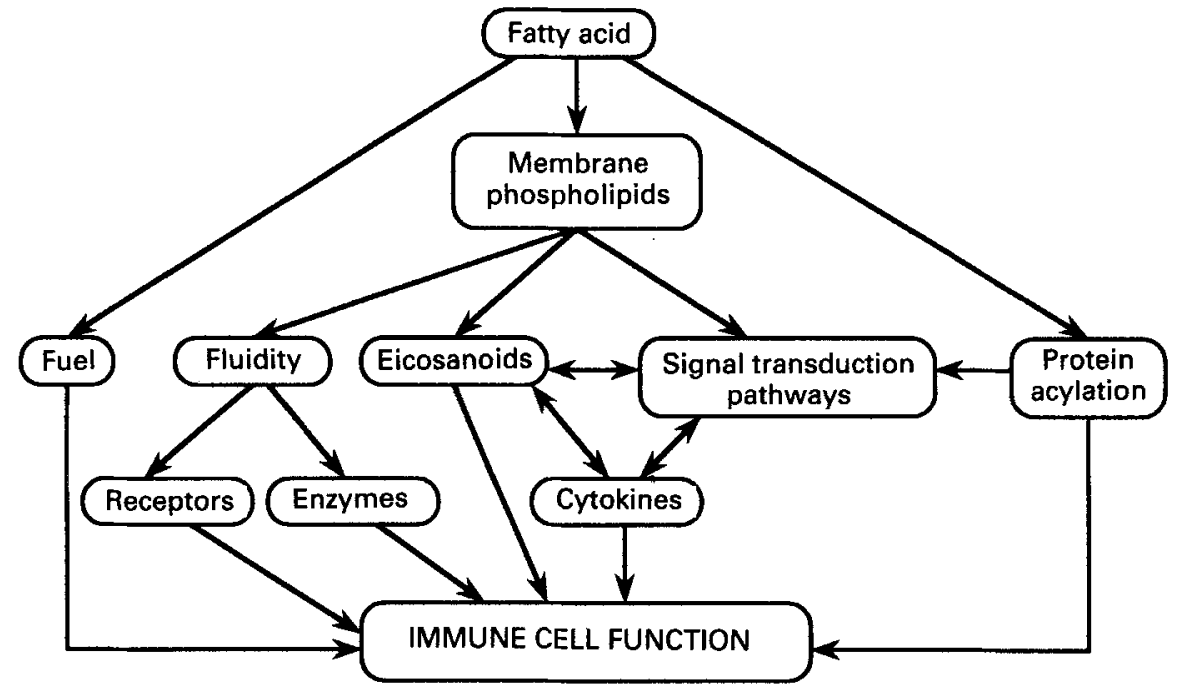

Fig. 2. Mechanisms by which fatty acids might affect immune cell function.

\section{EICOSANOIDS AND CELLS OF THE IMMUNE SYSTEM}

The precursors and pathways of eicosanoid synthesis

Eicosanoids are a family of oxygenated derivatives of dihomo- $\gamma$-linolenic, arachidonic and eicosapentaenoic acids. Eicosanoids include prostaglandins (PG) and thromboxanes (TX), which together are termed prostanoids, and leukotrienes (LT), lipoxins (LX), hydroperoxyeicosatetraenoic acids (HPETE) and hydroxyeicosatetraenoic acids (HETE). In most conditions the principal precursor for these compounds is arachidonic acid and the eicosanoids produced from arachidonic acid appear to have more potent biological functions than those formed from dihomo- $\gamma$-linolenic or eicosapentaenoic acids. The precursor PUFA is released from membrane phosphatidylcholine by the action of phospholipase $\mathrm{A}_{2}$ (EC 3.1.1.4) or from membrane phosphatidylinositol-4,5bisphosphate by the actions of phospholipase $C(E C$ 3.1.4.3) and a diacylglycerol lipase (EC 3.1.1.34).

The pathways of eicosanoid synthesis begin with cyclooxygenase, which yields the PG and TX (Fig. 3), or with the 5-, 12- or 15-lipoxygenases, which yield the LT, HPETE, HETE and LX (Fig. 4). A third pathway which operates through the microsomal cytochrome P-450 results in formation of epoxides which are converted to HETE. The amounts and types of eicosanoids synthesized are determined by the availability of arachidonic acid, by the activities of phospholipase $\mathrm{A}_{2}$ and phospholipase $\mathrm{C}$ and by the activities of cyclooxygenase and the lipoxygenases.

The major biologically-active products of the cyclooxygenase pathway are considered to be $\mathrm{PGA}_{2}, \mathrm{PGE}_{2}, \mathrm{PGI}_{2}$ (prostacyclin), $\mathrm{PGF}_{2 \alpha}$ and $\mathrm{TXA}_{2}$, although these are produced in a cell-specific manner. These compounds usually have a short half-life (e.g. $30 \mathrm{~s}$ for $\mathrm{PGI}_{2}$ and $\mathrm{TXA}_{2}$ released from platelets) and act locally to the cell from which they are produced. Their production is initiated by a particular stimulus (e.g. cytokines, growth factors, endotoxin, zymosan, oxygen free radicals, antigen-antibody complexes, 


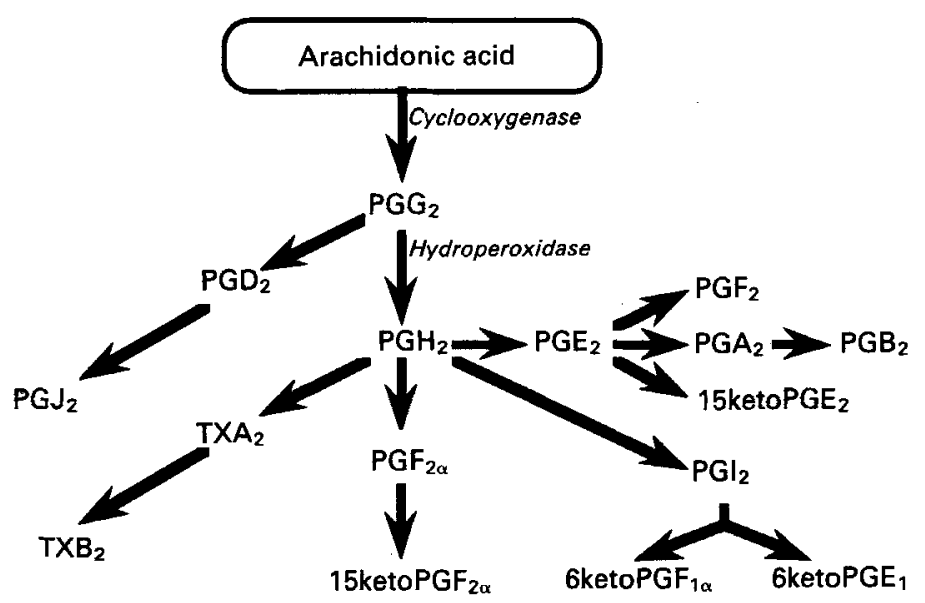

Fig. 3. Metabolism of arachidonic acid by the cyclooxygenase pathway. PG, prostaglandins; TX, thromboxanes.

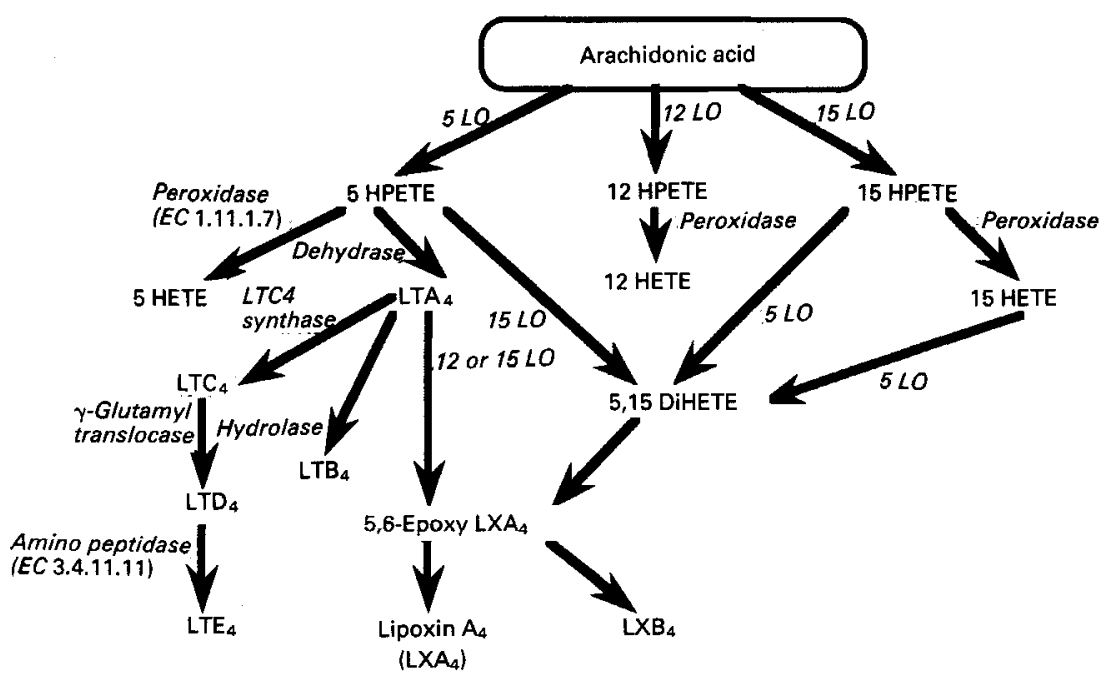

Fig. 4. Metabolism of arachidonic acid by the lipoxygenase pathways. LO, lipoxygenase; LT, leukotrienes; LX, lipoxins; HPETE, hydroperoxyeicosatetraenoic acids; HETE, hydroxyeicosatetraenoic acids.

bradykinin, collagen, thrombin) and, once produced, they themselves are able to modify the response to the stimulus. Different prostanoids have different, sometimes opposite, effects; for example, $\mathrm{TXA}_{2}$ increases platelet aggregation whereas $\mathrm{PGI}_{2}$ inhibits platelet aggregation. $\mathrm{PG}$ are associated with the inflammatory response and cyclooxygenase inhibitors include aspirin and related non-steroidal anti-inflammatory drugs. The synthesis of prostanoids has been reviewed recently (Hwang, 1989; Lands, 1991; Sardesai, 1992). 
The synthesis of eicosanoids from arachidonic acid by the lipoxygenase pathways has been reviewed in recent years (Parker, 1987; Lewis et al. 1990). Each of the lipoxygenase enzymes has a particular cellular distribution: 5-lipoxygenase is found in mast cells, monocytes, macrophages and granulocytes, 12-lipoxygenase is found in platelets and some epithelial cells and 15-lipoxygenase is found in young myeloid cells and some epithelial cells.

The $n-3$ PUFA, eicosapentaenoic and docosahexaenoic, competitively inhibit the oxygenation of arachidonic acid by cyclooxygenase. In addition, eicosapentaenoic acid (but not docosahexaenoic acid) is able to act as a substrate for both cyclooxygenase and 5-lipoxygenase. Thus, ingestion of fish oils which contain $n-3$ PUFA will result in a decrease in membrane arachidonic acid levels and a concomitant decrease in the capacity to synthesize eicosanoids from arachidonic acid; eicosapentaenoic acid gives rise to the 3-series PG and TX and the 5-series LT. The eicosanoids produced from eicosapentaenoic acid do not always have the same biological properties as the analogues produced from arachidonic acid. For example, $\mathrm{TXA}_{3}$ is less active than $\mathrm{TXA}_{2}$ in aggregating platelets and constricting blood vessels, $\mathrm{LTB}_{5}$ is less active than $\mathrm{LTB}_{4}$ with regard to chemotactic and aggregatory properties in human neutrophils and $\mathrm{PGE}_{3}$ is a less potent inhibitor of lymphocyte proliferation than $\mathrm{PGE}_{2}$. In contrast, $\mathrm{PGI}_{3}$ is as active as $\mathrm{PGI}_{2}$ in inhibiting platelet aggregation and promoting vasodilation.

Dihomo- $\gamma$-linolenic acid competes with arachidonic acid for cyclooxygenase and, therefore, decreases the production of cyclooxygenase products from arachidonic acid, whilst favouring the production of the 1-series $\mathrm{PG}$ and $\mathrm{TX}$ for which it is the precursor (e.g. $\mathrm{PGE}_{1}$ and $\mathrm{TXA}_{1}$; there is no $\mathrm{PGI}_{2}$ analogue formed from dihomo- $\gamma$-linolenic acid). Dihomo- $\gamma$-linolenic acid is converted to 3 -series leukotrienes via 5 -lipoxygenase; the 15-lipoxygenase converts it to 15-hydroxy-dihomo- $\gamma$-linolenic acid, which can inhibit 5 -lipoxygenase activity. The prostanoids generated from dihomo- $\gamma$-linolenic acid, like those generated from eicosapentaenoic acid, have different functional properties from those generated from arachidonic acid.

\section{The synthesis of eicosanoids by cells of the immune system}

The synthesis of $\mathrm{PGE}_{2}$ by mouse spleen cells and human mixed leucocytes was first reported by Ferraris et al. (1974). This study suggested that macrophages were the major source of the PG since partial removal of phagocytic cells decreased the production of $\mathrm{PGE}_{2}$ (Ferraris et al. 1974). Later studies using more homogeneous preparations of animal and human macrophages reported synthesis of a range of arachidonic acidderived cyclooxygenase and lipoxygenase products (for review, see Goldyne \& Stobo, 1981; Hwang, 1989). The exact profile of eicosanoids formed depends on the species and anatomical site of origin of the macrophages and the nature of the stimulus (see Hwang, 1989). $\mathrm{PGE}_{1}$ is also formed by macrophages but at a much lower level than $\mathrm{PGE}_{2}$, since there is much less dihomo- $\gamma$-linolenic acid than arachidonic acid present in macrophage phospholipids.

Although it is recognized that macrophages possess active cyclooxygenase and lipoxygenase enzymes, the studies concerning eicosanoid synthesis by lymphocytes have proved controversial. Synthesis of $\mathrm{PGE}_{2}$ has been reported for many lymphocyte preparations (for references, see Goldyne \& Stobo, 1981), but there was usually no attempt to remove contaminating macrophages. In contrast, very pure human lym- 
phocytes, containing less than $1 \%$ contaminating macrophages, failed to produce PG or TX when stimulated by mitogens (for references, see Goldyne, 1988), and highly purified $\mathrm{T}$-cells and $\mathrm{B}$-cells do not synthesize detectable levels of $\mathrm{PGE}_{2}$ or TXA $\mathrm{TX}_{2}$ (Kennedy et al. 1980). Furthermore, neither T- nor B-cell lines synthesize $\mathrm{PGE}_{2}$ or $\mathrm{TXA}_{2}$, whereas macrophage cell lines produce a range of eicosanoids (Kennedy et al. 1980). On the basis of these studies it has been concluded that lymphocytes do not possess the cyclooxygenase enzyme. There are reports that lymphocytes produce lipoxygenase products, including LTB $_{4}$ and 5-, 11- and 15-HETE (Goetzl, 1981; Pawlowski et al. 1983; Atluru et al. 1986). However, these studies did not use pure lymphocytes and it was shown that monocytes were the source of the lipoxygenase products in such preparations (Goldyne et al. 1984). It was later confirmed that pure preparations of lymphocytes and T-cell lines could not synthesize lipoxygenase products (Ferreri et al. 1986; Goldyne \& Seaman, 1987; Poubelle et al. 1987; Yi et al. 1988).

Lymphocytes and macrophages contain similar amounts of arachidonic acid in membrane phospholipids and mitogen-stimulated lymphocytes release arachidonic acid extracellularly (Parker et al. 1979). There is evidence that macrophages utilize this arachidonic acid for eicosanoid synthesis (Goldyne \& Stobo, 1982). Indeed, in the presence of lymphocytes, macrophages produce increased amounts of $\mathrm{PGE}_{2}$ in vitro. Thus, it seems that among immunocompetent cells, macrophages are the principal, and perhaps the only, source of eicosanoids, but that an interaction between lymphocytes and macrophages may exist.

\section{Effects of eicosanoids on cells of the immune system}

Not only are immune cells the source of eicosanoids, but they are subject to their regulatory effects; the most well documented effects are those of $\mathrm{PGE}_{2}$. In vivo, $\mathrm{PG}$ are involved in modulating the intensity and duration of inflammatory and immune responses. In chronic inflammatory conditions increased activity of suppressor T-cells and increased rates of $\mathrm{PGE}_{2}$ production are observed, and elevated $\mathrm{PGE}_{2}$ production has been observed in patients suffering from infections, whose T-cells show depressed functional responses. It is generally accepted that $\mathrm{PGE}_{2}$ is a regulator of immune cell functions; the age and type of target cell and the concentration of $\mathrm{PGE}_{2}$ determine the nature of the response.

$\mathrm{PG}$ appear to play a role in regulating the differentiation of both $\mathrm{T}$ and $\mathrm{B}$ lymphocytes; for example, $\mathrm{PGE}_{2}$ induces immature thymocytes to differentiate into mature $\mathrm{T}$-cells (Bach et al. 1975). In addition, the functions of T-cells, B-cells, natural killer (NK) cells and macrophages are modulated by eicosanoids; these effects are extensively reviewed by Goldyne \& Stobo (1981), Goodwin \& Cueppans (1983) and Hwang (1989). T-lymphocytes have receptors for $\mathrm{PGE}_{1}$ and $\mathrm{PGE}_{2}$ and these compounds suppress T-lymphocyte proliferation, T-cell-mediated cytotoxicity, interleukin (IL)-2 production and $\mathrm{NK}$ cell activity in vitro. In contrast, T-cells do not have receptors for PGA, PGF PG $_{1 \alpha}$ or $\mathrm{PGF}_{2 \alpha}$ and these eicosanoids do not affect $\mathrm{T}$-cell functions. B-cells have receptors for the E-series $P G$ and $P G E_{2}$ can influence antibody production. $P G$ inhibit production of cytokines including IL-1 and tumour necrosis factor (TNF) by macrophages. Some macrophage enzyme activities are also modulated by $\mathrm{PG}$, as is expression of major histocompatibility class II receptors. There are conflicting reports about the effects of LT on lymphocyte proliferation, but NK cell activity is enhanced by $\mathrm{LTB}_{4}$ (Rola- 


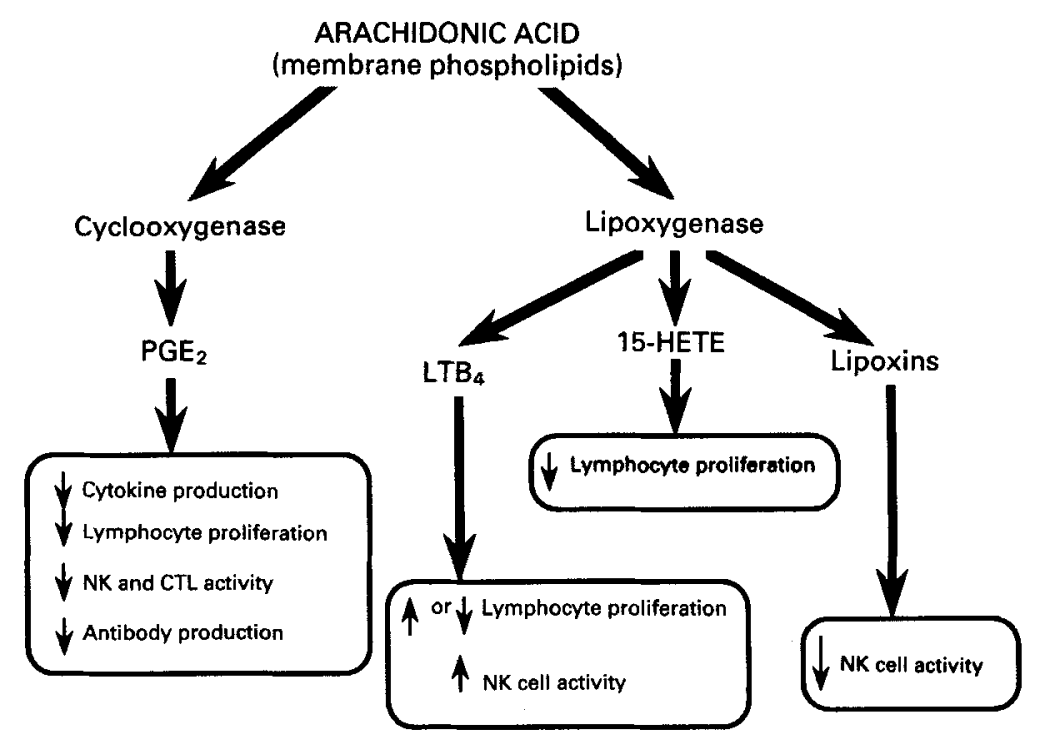

Fig. 5. Regulation of immune cell function by eicosanoids. $\mathrm{PGE}_{2}$, prostaglandin $\mathrm{E}_{2} ; \mathrm{LTB}_{4}$, leucotriene $\mathrm{B}_{4}$; 15-HETE, 15-hydroxyeicosatetraenoic acid; NK, natural killer; CTL, cytotoxic T-lymphocyte.

Pleszczynski et al. 1983). $\mathrm{LTB}_{4}$ and LTC 4 enhance IL-1 production by macrophages (Kunkel et al. 1982) and $\mathrm{LTB}_{4}$ enhances interferon- $\gamma$ production by lymphocytes (Rola-Pleszczynski et al. 1983). The effects of arachidonic acid-derived eicosanoids on lymphocyte functions are summarized in Fig. 5. Since they influence eicosanoid production, it is clear that fatty acids, particularly $n-3$ PUFA, can modulate immune cell functions by eicosanoid-mediated effects.

\section{Modulation of eicosanoid synthesis by fatty acids and dietary lipids}

Culture of macrophages with $n-3$ PUFA results in replacement of arachidonic acid in phospholipids by eicosapentaenoic acid (Magrum \& Johnston, 1983, 1985; Lokesh et al. 1988; Calder et al. 1990b). As a result of this modification, less arachidonic acid-derived eicosanoids are produced. Dietary lipid modulation also results in significant modification of the fatty acid composition of macrophages isolated from the peritoneal cavity of mice (Lokesh et al. 1986; Hardardottir \& Kinsella, 1992), rats (Magrum \& Johnston, 1983; Brouard \& Pascaud, 1990; Watanabe et al. 1991; Sherrington et al. 1995) or hamsters (Surette et al. 1995) and of monocytes isolated from human peripheral blood (Lee et al. 1985; Endres et al. 1989). It is widely reported that feeding laboratory animals $n-3$ PUFA-containing oils such as linseed or fish oil results in decreased production of arachidonic acid-derived eicosanoids (Magrum \& Johnston, 1983; Lokesh et al. 1986, 1988; Brouard \& Pascaud, 1990; Hardardottir \& Kinsella, 1991, 1992; Surette et al. 1995; Yaqoob \& Calder, 1995a; Table 1). Lee et al. (1985) and Endres et al. (1989) showed that fish oil supplementation of the human diet results in similar changes. These changes are accompanied by an increase in the production of eicosapentaenoic acid-derived eicosanoids. 
Table 1. Effect of dietary lipids on the production of eicosanoids by murine peritoneal macrophages (From Yaqoob \& Calder, 1995a)

(Mice were fed for 8 weeks on a low-fat $(25 \mathrm{~g} / \mathrm{kg})$ diet or on diets containing $200 \mathrm{~g}$ hydrogenated coconut oil, olive oil, safflower oil or fish oil $/ \mathrm{kg}$. Thioglycollate-elicited peritoneal macrophages were prepared and cultured with bacterial lipopolysaccharide for $8 \mathrm{~h}$. The medium was collected and assayed using enzyme-linked immunosorbent assays; concentrations are expressed as $\mathrm{ng} / \mathrm{ml}$. Values are means with their standard errors)

\begin{tabular}{|c|c|c|c|c|c|c|}
\hline \multirow[b]{2}{*}{ Diet } & \multicolumn{2}{|c|}{$\mathrm{PGE}_{2}$} & \multicolumn{2}{|c|}{$\mathrm{TXB}_{2}$} & \multicolumn{2}{|c|}{ 6ketoPGF $F_{1 \alpha}$} \\
\hline & Mean & SE & Mean & $\mathrm{SE}$ & Mean & $S E$ \\
\hline Low-fat & 73 & 7 & $0 \cdot 6$ & $0 \cdot 1$ & 0.7 & $0 \cdot 1$ \\
\hline Coconut oil & 52 & 12 & 0.5 & $0 \cdot 2$ & 0.7 & $0 \cdot 1$ \\
\hline Olive oil & 59 & 7 & 0.7 & $0 \cdot 1$ & 0.8 & $0 \cdot 1$ \\
\hline Safflower oil & 60 & 9 & $0 \cdot 8$ & $0 \cdot 1$ & 0.8 & $0 \cdot 1$ \\
\hline Fish oil & 18 & 2 & $0 \cdot 3$ & $0 \cdot 1$ & $0 \cdot 2$ & $0 \cdot 1$ \\
\hline
\end{tabular}

$\mathrm{PGE}_{2}$, prostaglandin $\mathrm{E}_{2} ; \mathrm{TXB}_{2}$, thromboxane $\mathrm{B}_{2} ;$ 6ketoPGF $1 \alpha$, 6-ketoprostaglandin $\mathrm{F}_{1 \alpha}$.

FATTY ACIDS AND LYMPHOCYTE FUNCTIONS IN VITRO

\section{Lymphocyte proliferation}

A number of studies have investigated the effects of adding fatty acids to lymphocytes in culture on mitogen-stimulated lymphocyte proliferation (Mertin et al. 1974; Offner \& Clausen, 1974; Mertin \& Hughes, 1975; Mihas et al. 1975; Weyman et al. 1975, 1977; Tsang et al. 1977; Buttke, 1984; Virella et al. 1989; Calder et al. 1990a , 1991, 1992; Calder \& Newsholme, 1992a,b; Kumar et al. 1992; Soyland et al. 1993; Rotondo et al. 1994). These studies show that oleic, linoleic, $\alpha$-linolenic, $\gamma$-linolenic, dihomo- $\gamma$-linolenic, arachidonic, eicosapentaenoic and docosahexaenoic acids inhibit concanavalin $\mathrm{A}$ (Con A)- and/or phytohaemagglutinin (PHA)-stimulated proliferation of lymphocytes isolated from rodent lymphoid tissues (lymph nodes, spleen, thymus) and from human peripheral blood and have been reviewed in detail elsewhere (Yaqoob \& Calder, 1993; Calder, 1995). The inhibition of lymphocyte proliferation by unsaturated fatty acids is dependent on the concentration of fatty acid used, the time during culture of fatty acid addition and the duration of exposure of the cells to the fatty acid. Most studies agree that the extent of inhibition is also partly dependent on degree of unsaturation of the fatty acid, with chain length also being important; the early studies showed that arachidonic acid caused the greatest inhibition of proliferation, while the later studies, which included a greater range of fatty acids, indicate an approximate order of potencies as:

oleic $<$ linoleic $=\alpha$-linolenic $<\gamma$-linolenic $=$ dihomo- $\gamma$-linolenic $=$ docosahexaenoic $<$ arachidonic $=$ eicosapentaenoic.

A number of studies have shown also inhibition of lymphocyte proliferation by at least some saturated fatty acids. Most studies agree that saturated fatty acids cause less inhibition than unsaturated fatty acids (Mertin \& Hughes, 1975; Calder et al. 1991, 1992; Calder \& Newsholme, 1992a,b; Soyland et al. 1993; Rotondo et al. 1994); there have been a number of reports of lack of inhibition by lauric and myristic acids (Weyman et al. 1975, 1977; Tsang et al. 1977; Calder et al. 1991, 1992; Calder \& Newsholme, 1992a,b; Soyland et al. 1993) and there appears to be general agreement that stearic acid is the 
most potent inhibitor of lymphocyte proliferation amongst the saturated fatty acids, causing a degree of inhibition similar to that of oleic acid (Calder et al. 1991, 1992; Calder \& Newsholme, 1992a,b; Soyland et al. 1993). Thus, amongst the saturated fatty acids the order of potencies appears to be:

$$
\text { lauric }=\text { myristic }<\text { palmitic }<\text { stearic } .
$$

In contrast to the findings of these studies, Kelly \& Parker (1979) reported that low concentrations (less than $5 \mu \mathrm{M}$ ) of some unsaturated fatty acids stimulated PHAstimulated proliferation of murine spleen lymphocytes; arachidonic acid was inhibitory even at very low concentrations. This may be because proliferating lymphocytes require an exogenous supply of unsaturated fatty acids; however, once a particular fatty acid concentration is exceeded (approximately 10-15 $\mu \mathrm{M}$ ), the fatty acids begin to exert inhibitory effects. This was borne out by the study of Kelly \& Parker (1979) in which higher concentrations of unsaturated fatty acids did cause inhibition of lymphocyte proliferation.

The proliferation of lymphocytes, both in vivo and in vitro, is dependent on the presence of various cytokines; thus, proliferation of lymphocytes can be measured in response to the provision of cytokines. Santoli et al. (1990) found that palmitic, oleic, linoleic, $\alpha$-linolenic, dihomo- $\gamma$-linolenic, arachidonic and eicosapentaenoic acids cause concentration-dependent inhibition of the proliferation of human peripheral-blood lymphocytes (PBL) in response to IL-2, with arachidonic acid causing the greatest inhibition and palmitic and oleic acids the least. Recently, Rotondo et al. (1994) showed that several unsaturated fatty acids inhibited the proliferation of murine thymic lymphocytes in response to either IL- 2 or IL-1 $\beta$; dihomo- $\gamma$-linolenic, arachidonic and eicosapentaenoic acids were the most inhibitory fatty acids. In accordance with these findings, Borofsky et al. (1992) found that some unsaturated fatty acids (dihomo$\gamma$-linolenic, arachidonic) inhibited the proliferation of an IL-2-dependent cell line.

Since most fatty acids are carried in the bloodstream as triacylglycerols (TAG) rather than in non-esterified form, the effect of different TAG on lymphocyte proliferation must be addressed. The only study to have investigated the effect of pure TAG on lymphocyte proliferation found that those containing linoleic, $\alpha$-linolenic or arachidonic acids caused concentration-dependent inhibition of Con A-stimulated proliferation of rat lymph-node lymphocytes, while TAG containing saturated fatty acids (myristic, palmitic, stearic) or oleic acid were without effect (Calder et al. 1994b).

The inhibitory effects of PUFA on lymphocyte proliferation are not mediated by eicosanoids (Santoli et al. 1990; Calder et al. 1992; Kumar et al. 1992; Soyland et al. 1993; Rotondo et al. 1994) or lipid peroxidation (Calder \& Newsholme, 1993; Soyland et al. 1993). The evidence for these conclusions is discussed in detail elsewhere (Calder, 1995).

When lymphocytes are stimulated in culture they undergo subtle changes in the fatty acid composition of their plasma membrane phospholipids (Anel et al. 1990; Calder et al. $1994 a$ ); in addition there is an increase in plasma membrane fluidity (Anel et al. 1990; Calder et al. 1994a). Addition of fatty acids to the culture medium results in their uptake by the cells and subsequent incorporation into phospholipids (Calder et al. 1994a). As a result, the fatty acid composition of the phospholipids is markedly changed (Calder et al. $1994 a$ ). Such manipulation of the fatty acid composition of the cells also results in significant changes in plasma membrane fluidity (Calder et al. 1994a). It is possible that these changes in some way affect the ability of the cells to respond optimally to mitogenic stimulation. 


\section{Lymphocyte-derived cytokine production}

The proliferation of lymphocytes depends on the production of IL-2. The possibility that fatty acids suppress proliferation by inhibiting the IL-2 production has been investigated by measuring the concentration of IL- 2 in the medium of mitogen-stimulated lymphocytes. Culture of Con A-stimulated rat lymph-node lymphocytes with oleic, linoleic, $\alpha$-linolenic, arachidonic, eicosapentaenoic or docosahexaenoic acids resulted in a $40-50 \%$ lower concentrations of IL- 2 in the culture medium than if the cells were cultured in the absence of fatty acids or in the presence of saturated fatty acids (Calder \& Newsholme, 1992a). Similarly, culture of human PBL with these unsaturated fatty acids resulted in $70-90 \%$ lower IL-2 concentrations in the culture medium (Calder \& Newsholme 1992b). These findings suggest that unsaturated fatty acids may affect IL-2 production by mitogen-stimulated lymphocytes. However, lymphocyte proliferation could not be returned to control levels by addition of exogenous IL-2 to the culture medium (Calder \& Newsholme, 1992a). Thus, unsaturated fatty acids may inhibit lymphocyte proliferation by exerting effects on two or more key processes, including IL-2 production.

\section{Lymphocyte-mediated cytolysis}

Lymphocyte-mediated cytolysis of target cells is performed by cytotoxic T-lymphocytes (CTL) and by NK cells. Richieri et al. (1990) showed that oleic, linoleic, $\alpha$-linolenic and arachidonic acids inhibit the extracellular release of the contents of the granules which are responsible for target-cell killing by rat spleen CTL; this observation suggests that these unsaturated fatty acids should inhibit CTL activity. Rice et al. (1981) reported that $\gamma$-linolenic acid significantly suppressed the NK-cell activity of human PBL, while oleic acid caused a marginal enhancement of this activity. More recently, Yamashita et al. (1986, 1991) showed that TAG containing either eicosapentaenoic or docosahexaenoic acid cause concentration-dependent inhibition of human peripheral-blood NK-cell activity.

\section{DIETARY LIPIDS AND LYMPHOCYTE FUNCTIONS}

\section{Lymphocyte proliferation}

Since mitogen-stimulated lymphocyte proliferation is relatively simple to measure in vitro and because it is believed to be a reliable measure of lymphocyte function in vivo, many studies have used this test to assess the effects of dietary lipids on lymphocytes. However, it is difficult to make direct comparisons between these studies because they differ greatly in the amount of fat used, the composition of other dietary components, the amount and type of antioxidant present, the duration of feeding and the age, sex and species of animal used. Furthermore, it is now apparent that the result of ex vivo lymphocyte proliferation measurements is strongly influenced by the cell culture conditions, particularly the nature of the serum used (Yaqoob et al. 1994a).

Studies in laboratory animals. A number of studies have shown that feeding rats or mice diets rich in $n-6$ PUFA, such as maize, soyabean, safflower or sunflower oils, results in suppressed ex vivo Con A- or PHA-stimulated proliferation of spleen lymphocytes compared with feeding diets rich in saturated fatty acids, such as lard, tallow or hydrogenated coconut oil, or low-fat diets (Kollmorgen et al. 1979; Erickson et al. 1980; 
Levy et al. 1982; Locniskar et al. 1983; Morrow et al. 1985; Marshall \& Johnston, 1985; Kramer et al. 1986; Olson et al. 1987; Calder et al. 1995). In contrast, some studies have shown that feeding rodents $n-6$ PUFA-rich diets does not affect (Cathcart et al. 1987) or enhances (Ossman et al. 1980) ex vivo T-cell proliferation. The results of investigations on B-lymphocyte proliferation are also contradictory: it has been reported that $n-6$ PUFA-rich diets suppress (Ossman et al. 1980), do not affect (Erickson et al. 1980; Cathcart et al. 1987; Olson et al. 1987) or enhance (Ossman et al. 1980) ex vivo lipopolysaccharide (LPS)-stimulated proliferation of rodent spleen lymphocytes. Friend et al. (1980) reported that feeding guinea-pigs on a maize-oil-rich diet results in suppressed lymph-node lymphocyte proliferation in response to PHA, while de Deckere et al. (1988) reported that Con A- or PHA-stimulated proliferation of rabbit PBL was unaffected by feeding palm or sunflower oils.

There is little doubt that many of the differences in the effects reported by these studies are due to differences in the level of fat fed, the duration of feeding and the cell culture conditions used when measuring proliferation. There also appear to be differences due to the anatomical site of origin of the lymphocytes and the species of animal used. The latter is clearly illustrated by the study of Alexander \& Smythe (1988) who showed that feeding fish oil to BALB/c mice significantly decreased Con A-stimulated spleen lymphocyte proliferation compared with feeding lard or maize oil, whereas feeding NZB/NZW mice fish oil had no effect on spleen lymphocyte proliferation. That the anatomical site of origin of the lymphocytes to be tested may affect the experimental result obtained is shown by the report of Locniskar et al. (1983) that feeding rats on maize oil suppressed the proliferation of spleen, but not lymph node, lymphocytes in response to Con A or PHA.

In recent years there has been increased interest in the effects of $n-3$ PUFA-containing oils (rapeseed, linseed, fish) on lymphocyte proliferation. Marshall \& Johnson (1985) showed that feeding rats on a linseed oil-rich diet suppressed spleen T-lymphocyte proliferation compared with feeding hydrogenated coconut oil. Kelley et al. (1988) found that feeding fish oil to rabbits suppressed the proliferation of spleen $\mathrm{T}$ - and peripheral blood T- and B-lymphocytes compared with feeding hydrogenated coconut, safflower or linseed oils. Fritsche et al. (1991) showed that feeding fish oil to chickens significantly suppressed spleen lymphocyte proliferation in response to Con A or pokeweed (Phytolacca americana) mitogen (PWM) compared with feeding linseed, rapeseed or maize oils or lard; furthermore, feeding linseed oil suppressed proliferation compared with feeding rapeseed or maize oil or lard. These effects were demonstrated when the cells were cultured in autologous serum, but were lost if the cells were cultured in fetal calf serum (FCS). Similarly, Meydani et al. (1985) reported that feeding cebus (Cebus apella) or squirrel (Saimiri sciureus) monkeys on a maize oil diet for several years resulted in suppression of PBL proliferation in response to either PHA or PWM, compared with feeding coconut oil, but that these effects were observed only if the cells were cultured in autologous serum; FCS completely masked the differential effect of the diets. Culture of cells in FCS may explain the lack of effect on spleen lymphocyte proliferation of feeding fish, linseed, safflower or olive oils to mice recently reported by Berger et al. (1993).

Recently, we reported the results of a direct comparison of feeding weanling rats for 10 weeks on diets containing $200 \mathrm{~g}$ hydrogenated coconut oil, olive oil, safflower oil, evening primrose (Oenothera biennis) oil or fish (menhaden) oil $/ \mathrm{kg}$; all other 


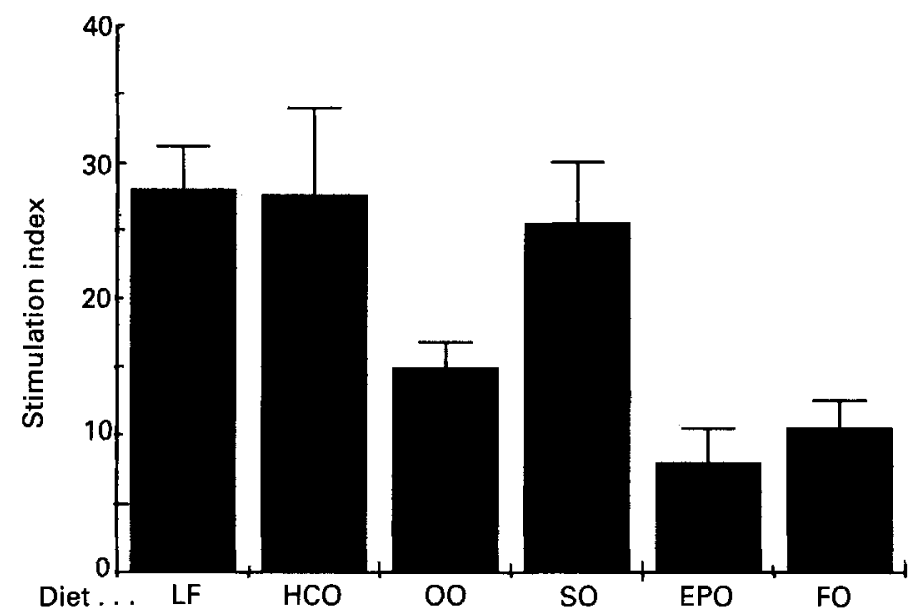

Fig. 6. Effect of dietary lipids on rat lymphocyte proliferation. Rats were fed for 10 weeks on a low-fat (25 g/kg) diet (LF) or on diets containing $200 \mathrm{~g}$ hydrogenated coconut oil (HCO), olive oil (OO), safflower oil (SO), evening primrose oil (EPO) or fish oil (FO). The proliferation of lymph node lymphocytes in response to the T-cell mitogen concanavalin A was measured as $\left[{ }^{3} \mathrm{H}\right]$ thymidine incorporation and is expressed as a stimulation index. Values are means with their standard errors represented by vertical bars. Data are taken from Yaqoob et al. $(1994 a)$.

components of the diets, including the levels of antioxidants, were identical. Feeding each of these diets suppressed Con A- and PHA-stimulated spleen-lymphocyte proliferation ex vivo compared with feeding on a low-fat diet, and feeding the olive-oil, evening-primrose-oil or fish-oil diets suppressed Con A- and PHA-stimulated proliferation of lymph-node lymphocytes compared with feeding the low-fat hydrogenatedcoconut-oil or safflower-oil diets (Yaqoob et al. 1994a; Fig. 6). For both cell types the effects of the dietary manipulation were masked if the cells were cultured in FCS rather than autologous serum. We have recently shown that the effects of feeding these diets to more mature rats on spleen-lymphocyte proliferation are very similar to the effects of feeding weanling rats (Sanderson et al. 1995a). Furthermore, we found that the diets which appear to be particularly immunosuppressive (i.e. olive, evening primrose and fish oils) decrease the level of expression of adhesion molecules (CD2, intercellular adhesion molecule 1 (CD54), leucocyte functional antigen 1 (CD11a)) on resting and/or mitogenstimulated spleen lymphocytes (Sanderson et al. 1995a). Spleen lymphocytes from animals fed on these diets also showed a lower level of expression of the IL-2 receptor following mitogenic stimulation (Sanderson et al. 1995a). Thus, we proposed that the immunomodulatory effects of dietary lipids may be due to the decreased level of expression of key surface molecules.

The use of a whole-blood culture system to test the effects of fatty acids on lymphocyte functions avoids the removal of erythrocytes and the loss of non-cellular physiological components normally in contact with the cells in the circulation. It also avoids the need for addition of serum, either autologous or from a different species. Importantly, the technique has the advantage that the ratios between different cell types and the ratios between cells and components such as growth factors and nutrients are the same as those 
in vivo. It was found that feeding rats for 10 weeks on diets containing hydrogenated coconut oil, olive oil or fish oil suppressed the proliferation of lymphocytes in response to low concentrations of Con A or PHA in whole-blood culture compared with feeding a low-fat diet, or diets containing safflower or evening primrose oil (Yaqoob et al. 1995).

Studies in man. Kelley et al. $(1989,1992)$ reported that a reduction in total fat intake enhanced PBL proliferation in response to Con A or PHA, suggesting that high-fat diets might suppress human lymphocyte proliferation. The studies of the effects of dietary lipid manipulation on human lymphocyte proliferation have been restricted to investigating the effects of fish oils and fish-oil-derived fatty acids. Meydani et al. (1991) reported the results of supplementing the diets of healthy young (22-33 years of age) or older (51-68 years of age) women with encapsulated $n-3$ PUFA (approximately $2 \cdot 4 \mathrm{~g} / \mathrm{d}$ ) for 12 weeks; the mitogenic response of PBL to PHA was lowered after 12 weeks of supplementation in the older women. Virella et al. (1991) found that feeding healthy volunteers $8 \mathrm{~g}$ fish oil/d did not affect the response of PBL to Con A or PHA, although there was a trend towards a decrease in the response to anti-CD3. Recently, Meydani et al. (1993) reported a decreased response of PBL to Con A or PHA following supplementation of volunteers on a low-fat low-cholesterol diet with encapsulated $n-3$ PUFA, while Endres et al. (1993) found that $18 \mathrm{~g}$ fish oil/d for 6 weeks resulted in lowered PHA-stimulated proliferation of PBL 10 weeks after supplementation had ended (but not at the end of the supplementation period).

\section{Lymphocyte-mediated cytolysis}

Olson et al. (1987) showed that feeding weanling mice on 50 or 200 g soyabean oil $/ \mathrm{kg}$ diet for 9 months resulted in suppression of spleen CTL activity, with the cells from the 200 $\mathrm{g} / \mathrm{kg}$ group having lower activity. This finding is supported by Erickson (1984) who found that feeding mice on 80 or $200 \mathrm{~g}$ safflower oil $/ \mathrm{kg}$ diet for 4 weeks decreased spleen CTL activity compared with feeding on a fat-free diet, a low-fat diet (containing maize oil) or diets containing 80 or $200 \mathrm{~g}$ hydrogenated coconut oil/kg. Fritsche \& Johnston (1989, 1990) reported that CTL activity of mouse spleen lymphocytes was lower after feeding mice on $100 \mathrm{~g}$ fish oil $/ \mathrm{kg}$ diet for up to 10 weeks than after feeding $100 \mathrm{~g}$ linseed oil $/ \mathrm{kg}$ diet. Feeding chickens diets containing $70 \mathrm{~g}$ fish or linseed oil $/ \mathrm{kg}$ significantly suppressed spleen CTL activity compared with diets containing $70 \mathrm{~g}$ lard or maize oil $/ \mathrm{kg}$ (Fritsche \& Cassity, 1992).

Erickson \& Schumacher (1989) reported no effect of feeding mice for 4 weeks on diets containing 50 or $200 \mathrm{~g}$ palm or safflower oil $/ \mathrm{kg}$ on spleen NK-cell activity compared with feeding on a low-fat diet. Similarly, Leung \& Ip (1986) showed little effect of feeding 200 $\mathrm{g}$ maize oil/ $\mathrm{kg}$ diet to rats for up to $87 \mathrm{~d}$ on spleen NK activity, and Fritsche \& Johnston (1989) showed no difference in rat spleen NK-cell activity following the feeding of diets rich in maize or linseed oil. In contrast to these studies, Morrow et al. (1985) showed that feeding weanling mice on $90 \mathrm{~g}$ lard or maize oil $/ \mathrm{kg}$ decreased spleen NK-cell activity compared with feeding $10 \mathrm{~g}$ maize oil $/ \mathrm{kg}$; the $90 \mathrm{~g}$ lard $/ \mathrm{kg}$ diet caused a greater decrease than the $90 \mathrm{~g}$ maize oil $/ \mathrm{kg}$ diet. Meydani et al. (1988) found that feeding young mice on a diet containing $100 \mathrm{~g}$ fish oil $/ \mathrm{kg}$ for 6 weeks caused a decrease in spleen NK-cell activity compared with feeding chow or $100 \mathrm{~g}$ maize oil $/ \mathrm{kg}$; there were no differences in NK-cell activity when these diets were fed to older mice. Fritsche \& Johnston (1990) reported that feeding mice on a diet containing $100 \mathrm{~g}$ fish oil $/ \mathrm{kg}$ suppressed spleen NK-cell activity 


\section{Table 2. Effect of dietary lipids on rat natural-killer-cell activity (From Yaqoob et al. 1994b)}

(Rats were fed for 10 weeks on a low-fat $(25 \mathrm{~g} / \mathrm{kg})$ diet or on diets containing $200 \mathrm{~g}$ hydrogenated coconut oil, olive oil, safflower oil, evening primrose oil or fish oil/kg. The natural-killer-cell activity of spleen lymphocytes towards YAC-1 murine lymphoma cells was determined using a $\mathrm{Cr}$-release assay; lymphocyte:target cell (L:T) values used were $100: 1,50: 1$ and $25: 1$. Values are means with their standard errors)

\begin{tabular}{|c|c|c|c|c|c|c|}
\hline \multirow{3}{*}{$\begin{array}{l}\text { L:T } \ldots \\
\text { Diet }\end{array}$} & \multicolumn{6}{|c|}{$\%$ Cytolysis } \\
\hline & \multicolumn{2}{|c|}{$100: 1$} & \multicolumn{2}{|c|}{$50: 1$} & \multicolumn{2}{|c|}{$25: 1$} \\
\hline & Mean & $\mathrm{SE}$ & Mean & SE & Mean & SE \\
\hline Low-fat & $46 \cdot 5$ & $2 \cdot 0$ & $29 \cdot 7$ & $2 \cdot 8$ & $17 \cdot 7$ & $2 \cdot 1$ \\
\hline Coconut oil & $40 \cdot 4$ & $2 \cdot 4$ & $22 \cdot 9$ & $1 \cdot 5$ & $11 \cdot 5$ & 0.6 \\
\hline Olive oil & $36 \cdot 4$ & $2 \cdot 8$ & $20 \cdot 8$ & $1 \cdot 7$ & $9 \cdot 3$ & 0.9 \\
\hline Safflower oil & $42 \cdot 1$ & 1.5 & $24 \cdot 2$ & $1 \cdot 3$ & $11 \cdot 2$ & $1 \cdot 1$ \\
\hline Evening primrose oil & $40 \cdot 7$ & 0.7 & $19 \cdot 1$ & $2 \cdot 6$ & $8 \cdot 9$ & $0 \cdot 2$ \\
\hline Fish oil & $29 \cdot 4$ & $2 \cdot 1$ & $13 \cdot 6$ & $0 \cdot 7$ & $5 \cdot 0$ & 0.3 \\
\hline
\end{tabular}

compared with a $100 \mathrm{~g}$ linseed oil $/ \mathrm{kg}$ diet. In the study of Berger et al. (1993) female mice were fed for 5 months on diets containing $100 \mathrm{~g}$ olive, safflower, linseed or fish oil $/ \mathrm{kg}$ and the spleen NK-cell activity of the pups was determined before they were weaned; the activity was lower in the fish oil group than in the safflower or olive oil groups. Recently, Yaqoob et al. (1994b) fed weanling rats for 10 weeks on a low-fat diet or on diets containing $200 \mathrm{~g}$ hydrogenated coconut, olive, safflower, evening primrose or fish oil/ $/ \mathrm{kg}$ before measuring spleen NK-cell activity. It was found that feeding each of the high-fat diets resulted in lower NK-cell activity compared with feeding the low-fat diet; the fish-oil diet was the most suppressive followed by the olive-oil and evening-primrose-oil diets (Yaqoob et al. 1994b; Table 2). Similar results have been found in more mature rats fed on these diets for 12 weeks (Sanderson et al. 1995a).

No studies have investigated the effect of dietary lipids on human NK-cell activity, although Barone et al. (1989) and Hebert et al. (1990) reported that a reduced fat intake is associated with a significant increase in NK-cell activity of PBL suggesting that high fat consumption will suppress NK-cell activity in man. Yamashita et al. (1991) have shown that intravenous injection of a TAG containing eicosapentaenoic acid into healthy human volunteers resulted in suppression of peripheral-blood NK-cell activity $24 \mathrm{~h}$ later.

\section{Lymphocyte-derived cytokine production}

In contrast to the large number of studies of the effects of dietary lipids, especially fish oils, on the ex vivo production of macrophage-derived cytokines (see p. 142), there have been only three studies on lymphocyte-derived cytokines. The only animal study which has been reported to date involved feeding weanling mice for 8 weeks on a low-fat diet or on diets containing $200 \mathrm{~g}$ hydrogenated coconut, olive, safflower or fish oil $/ \mathrm{kg}$; the spleen lymphocytes were subsequently stimulated with Con A (Yaqoob \& Calder, 1995b). This study found that the concentration of IL-2 was higher in the medium of spleen lymphocytes from mice fed on olive or safflower oil than in the medium of cells from mice fed on the low-fat diet or hydrogenated coconut oil; feeding fish oil had no effect on 
the IL-2 concentration in the medium. However, mitogen-stimulated spleen lymphocytes from mice fed on olive oil, safflower oil or fish oil produced less IL-4 and IL-10 than those from mice fed on the low-fat or hydrogenated-coconut-oil diets (Yaqoob \& Calder $1995 \mathrm{~b}$ ). Two studies have investigated the effects of consumption of fish-oil capsules by healthy human volunteers on subsequent IL-2 production by PBL (Meydani et al. 1991; Endres et al. 1993). Both of these studies showed that dietary supplementation with fish-oil capsules lowers ex vivo IL-2 production.

\section{DIETARY LIPIDS AND THE PRODUCTION OF MACROPHAGE-DERIVED MEDIATORS}

\section{Cytokines}

Since cytokine production by macrophages is regulated by eicosanoids and since dietary lipids affect eicosanoid production (see p. 134), it might be expected that dietary lipids, especially those containing $n-3$ PUFA, will affect cytokine production. A number of studies have reported that feeding rodents $n-3$ PUFA-containing oils results in enhanced production of TNF ex vivo (Lokesh et al. 1990; Hardardottir \& Kinsella, 1991, 1992; Turek et al. 1991; Watanabe et al. 1991; Chang et al. 1992), although there are reports of decreased production (Billiar et al. 1988; Yaqoob \& Calder, 1995a; Table 3) or no effect (Tappia \& Grimble, 1994) after feeding fish oil. A recent study showed that dietary olive, maize and fish oils increase IL-6 production by rat peritoneal macrophages (Tappia \& Grimble, 1994), while an earlier study reported increased IL-1 production after feeding fish oil (Lokesh et al. 1990). Again, however, there are contradictory reports (Billiar et al. 1988; Yaqoob \& Calder, 1995a; Table 3). The most likely reason for the variations in experimental observations is the differing protocols used; studies have varied in the amount of fat given $(100-300 \mathrm{~g} / \mathrm{kg})$ and the duration of feeding time (4-10 weeks), the species of animal used (mouse, rat), the type of macrophage used (peritoneal, Kupffer) and its state of activation at harvesting (resident, elicited), the stimulus used to elicit cytokine production (LPS, $\mathrm{Ca}$ ionophore, another cytokine), the type of serum present

\section{Table 3. Effect of dietary lipids on the production of cytokines by murine peritoneal macrophages (From Yaqoob \& Calder, 1995a)}

(Mice were fed for 8 weeks on a low-fat $(25 \mathrm{~g} / \mathrm{kg}$ ) diet or on diets containing $200 \mathrm{~g}$ hydrogenated coconut oil, olive oil, safflower oil or fish oil $/ \mathrm{kg}$. Thioglycollate-elicited peritoneal macrophages were prepared and cultured with bacterial lipopolysaccharide for $8 \mathrm{~h}$ (TNF- $\alpha$ ) or $24 \mathrm{~h}$ (IL-1, IL-6). The medium was collected and assayed using enzyme-linked immunosorbent assays; concentrations are expressed as $\mathrm{ng} / \mathrm{ml}$. Values are means with their standard errors)

\begin{tabular}{|c|c|c|c|c|c|c|}
\hline \multirow[b]{2}{*}{ Diet } & \multicolumn{2}{|c|}{ IL-1 } & \multicolumn{2}{|c|}{ IL-6 } & \multicolumn{2}{|c|}{$\mathrm{TNF}-\alpha$} \\
\hline & Mean & $\mathrm{SE}$ & Mean & $\mathrm{SE}$ & Mean & $\mathrm{SE}$ \\
\hline Low-fat & 0.49 & 0.02 & $10 \cdot 4$ & $1 \cdot 2$ & 0.32 & $0 \cdot 16$ \\
\hline Coconut oil & 0.45 & 0.01 & $10 \cdot 0$ & 1.4 & 0.54 & $0 \cdot 14$ \\
\hline Olive oil & 0.47 & 0.03 & $11 \cdot 2$ & $0 \cdot 3$ & 0.09 & 0.02 \\
\hline Safflower oil & 0.42 & 0.02 & $10 \cdot 3$ & 1.9 & $0 \cdot 17$ & 0.08 \\
\hline Fish oil & $0 \cdot 33$ & 0.13 & $4 \cdot 7$ & $0 \cdot 8$ & $0 \cdot 13$ & $0 \cdot 05$ \\
\hline
\end{tabular}

IL, interleukins; TNF- $\alpha$, tumour necrosis factor- $\alpha$. 
Table 4. Effect of dietary lipids on the production of superoxide, hydrogen peroxide and nitric oxide by murine peritoneal macrophages (From Yaqoob \& Calder, 1995a)

(Mice were fed for 8 weeks on a low-fat $(25 \mathrm{~g} / \mathrm{kg}$ ) diet or on diets containing $200 \mathrm{~g}$ hydrogenated coconut oil, olive oil, safflower oil or fish oil $/ \mathrm{kg}$. Thioglycollate-elicited peritoneal macrophages were prepared and cultured with a phorbol ester (superoxide, hydrogen peroxide) or bacterial lipopolysaccharide (nitric oxide) for $2 \mathrm{~h}$. The medium was collected and assayed using standard assays. Values are means with their standard errors)

\begin{tabular}{|c|c|c|c|c|c|c|}
\hline \multirow[b]{3}{*}{ Diet } & \multicolumn{6}{|c|}{ Rate of production ( $\mathrm{nmol} / 2 \mathrm{~h}$ per $10^{5}$ cells) } \\
\hline & \multicolumn{2}{|c|}{ Superoxide } & \multicolumn{2}{|c|}{$\mathrm{H}_{2} \mathrm{O}_{2}$} & \multicolumn{2}{|c|}{ NO } \\
\hline & Mean & SE & Mean & $\mathrm{SE}$ & Mean & $\mathrm{SE}$ \\
\hline Low-fat & $97 \cdot 2$ & $12 \cdot 2$ & $80 \cdot 4$ & $30 \cdot 0$ & $6 \cdot 2$ & $1 \cdot 5$ \\
\hline Coconut oil & $95 \cdot 6$ & $5 \cdot 9$ & $62 \cdot 4$ & $30 \cdot 0$ & $10 \cdot 6$ & $0 \cdot 7$ \\
\hline Olive oil & $104 \cdot 6$ & $11 \cdot 9$ & $124 \cdot 8$ & $55 \cdot 2$ & $11 \cdot 3$ & $2 \cdot 2$ \\
\hline Safflower oil & $103 \cdot 6$ & $10 \cdot 7$ & $84 \cdot 0$ & $43 \cdot 2$ & $16 \cdot 0$ & 0.8 \\
\hline Fish oil & $127 \cdot 5$ & $19 \cdot 7$ & $416 \cdot 4$ & $86 \cdot 4$ & $14 \cdot 6$ & $2 \cdot 6$ \\
\hline
\end{tabular}

in ex vivo macrophage culture (none, fetal calf, autologous) and its concentration, the duration of ex vivo macrophage culture and the method used to measure cytokine concentration (bioassay, enzyme-linked immunosorbent assay). In agreement with some of these animal experiments, Endres et al. (1989, 1993) and Meydani et al. (1991) found that fish oil supplementation in man diminished the ability of peripheral-blood monocytes to produce TNF, IL-1 $\alpha$ and IL-1 $\beta$ ex vivo, while Meydani et al. (1991) also reported decreased IL- 6 production. These studies are supported by the in vitro observations that fish oil and eicosapentaenoic acid inhibit IL-1 production by a macrophage-like cell line and by human monocytes (Watson et al. 1990; Baldie et al. 1993).

\section{Reactive oxygen species and nitric oxide}

The enzymes which result in synthesis of superoxide, $\mathrm{H}_{2} \mathrm{O}_{2}$ and $\mathrm{NO}$ are regulated by eicosanoids, cytokines and protein kinase $\mathrm{C}$. Therefore, dietary lipids might affect the production of reactive oxygen species and $\mathrm{NO}$ by macrophages and so regulate the cytotoxic activities of these cells. The effects of dietary lipid manipulation upon the production of superoxide, $\mathrm{H}_{2} \mathrm{O}_{2}$ and $\mathrm{NO}$ have recently been reported (Yaqoob \& Calder, 1995a). It was found that peritoneal macrophages from mice fed on $200 \mathrm{~g}$ fish oil $/ \mathrm{kg}$ for 8 weeks produced more superoxide and $\mathrm{H}_{2} \mathrm{O}_{2}$ in response to stimulation by a phorbol ester than macrophages from mice fed on a low-fat diet or diets containing $200 \mathrm{~g}$ hydrogenated coconut, olive or safflower oil/kg (Table 4). Furthermore, macrophages from mice fed on the olive-, safflower- or fish-oil diets produced more NO in response to stimulation with LPS than those from mice fed on the low-fat diet (Table 4). Since superoxide and $\mathrm{H}_{2} \mathrm{O}_{2}$ are important macrophage-derived cytotoxic agents these observations suggest that dietary lipid manipulation could affect the killing of microbial or tumour cells by macrophages. NO appears to regulate lymphocyte functions and so dietary lipid-induced modification of its generation from macrophages could affect lymphocyte activity. 


\section{CONCLUDING REMARKS}

It is now apparent that both eicosanoids and unsaturated fatty acids are potent modulators of lymphocyte and macrophage functions in vitro. Although some of the effects of unsaturated fatty acids may be brought about by modulation of the amount and types of eicosanoids made, it is clear that fatty acids can also elicit their effects by eicosanoid-independent mechanisms. Inclusion in the diet of high levels of certain lipids, particularly those containing $n-3$ PUFA, markedly affects the functions of cells of the immune system subsequently tested in vitro. Cellular components of both natural and acquired immunity are affected. However, there is great variation in the experimental protocols that have been used and, as a result, many contradictory observations have been made. In particular, the nature of the conditions used for ex vivo testing of immune cell functions appears to influence the measurements made. In vivo tests are perhaps the most appropriate approach for determining the effect of different dietary lipids on immune function. Using a popliteal lymph node weight assay it has been found that feeding rats on a diet containing $200 \mathrm{~g}$ fish oil $/ \mathrm{kg}$ suppresses both graft $v$. host and host $v$. graft responses compared with feeding a low-fat diet or diets containing $200 \mathrm{~g}$ hydrogenated coconut oil, olive oil, safflower oil or evening primrose oil $/ \mathrm{kg}$ (Sanderson et al. 1995b). Such fish-oil-induced immunosuppression in vivo may be of use as a therapy for disorders which involve an inappropriately-activated immune response such as rheumatoid arthritis (Sperling et al. 1987; Kremer et al. 1990), psoriasis (Bittiner et al. 1988), atopic dermatitis (Bjorneboe et al. 1987) and multiple sclerosis (Bates et al. 1989) or in the enhancement of graft survival (Homan van der Heide et al. 1993).

\section{REFERENCES}

Alexander, N. J. \& Smythe, N. L. (1988). Dietary modulation of in vitro lymphocyte function. Annals of Nutrition and Metabolism 32, 192-199.

Anel, A., Naval, J., Gonzalez, B., Torres, J. M., Mishal, Z., Uriel, J. \& Pineiro, A. (1990). Fatty acid metabolism in human lymphocytes. Biochimica et Biophysica Acta 1044, 323-331.

Atluru, D., Lianos, E. A. \& Goodwin, J. S. (1986). Arachidonic acid inhibits 5-lipoxygenase in human T cells. Biochemical and Biophysical Research Communications 135, 670-676.

Bach, M. A., Fournier, C. \& Bach, J. F. (1975). Regulation of theta-antigen expression by agents altering cyclic AMP level and by thymic factor. Annals of the New York Academy of Sciences 249, 316-320.

Baldie, G., Kaimakamis, D. \& Rotondo, D. (1993). Fatty acid modulation of cytokine release from human monocytic cells. Biochimica et Biophysica Acta 1179, 125-133.

Barone, J., Herbert, J. R. \& Reddy, M. M. (1989). Dietary fat and natural killer cell activity. American Journal of Clinical Nutrition 50, 861-867.

Bates, D., Cartlidge, N. E. F., French, J. M., Jackson, M. J., Nightingale, S., Shaw, D. A., Smith, S., Woo, E., Hawkins, S. A., Millar, J. H. D., Belin, J., Conroy, D. M., Gill, S. K., Sidey, M., Smith, A. D., Thompson, R. H. S., Zilkha, K., Gale, M. \& Sinclair, H. M. (1989). A double-blind controlled trial of long chain $n-3$ polyunsaturated fatty acids in the treatment of multiple sclerosis. Journal of Neurology, Neurosurgery and Psychiatry 52, 18-22.

Berger, A., German, J. B., Chiang, B. L., Ansari, A. A., Keen, C. L., Fletcher, M. P. \& Gershwin, M. R. (1993). Influence of feeding unsaturated fats on growth and immune status of mice. Journal of Nutrition 123, 225-233.

Bialick, R., Gill, R., Berke, G. \& Clark, W. R. (1984). Modulation of cell-mediated cytotoxicity function after alteration of fatty acid composition in vitro. Journal of Immunology 132, 81-87.

Billiar, T., Bankey, P., Svingen, B., Curran, R. D., West, M. A., Holman, R. T., Simmons, R. L. \& Cerra, F. B. (1988). Fatty acid uptake and Kupffer cell function: fish oil alters eicosanoid and monokine production to endotoxin stimulation. Surgery 104, 343-349. 
Bittiner, S. B., Tucker, W. F. G., Cartwright, I. \& Bleehen, S. S. (1988). A double-blind, randomised, placebo-controlled trial of fish oil in psoriasis. Lancet $\mathbf{i}, 378-380$.

Bjorneboe, A., Soyland, E., Bjorneboe, G.-E. A., Rajka, G. \& Drevon, C. A. (1987). Effect of dietary supplementation with eicosapentaenoic acid in the treatment of atopic dermatitis. British Journal of Dermatology 117, 463-469.

Borofsky, M. A., Zurier, R. B., Rosenbaum, H., Weiner, D. B. \& Williams, W. V. (1992). Effects of polyunsaturated fatty acids on interleukin-2-dependent $T$ cell growth. Immunology Research 11, 154-164.

Brenner, R. R. (1984). Effect of unsaturated fatty acids on membrane structure and enzyme kinetics. Progress in Lipid Research 23, 69-96.

Brouard, C. \& Pascaud, M. (1990). Effects of moderate dietary supplementations with $n-3$ fatty acids on macrophage and lymphocyte phospholipids and macrophage eicosanoid synthesis in the rat. Biochimica et Biophysica Acta 1047, 19-28.

Buttke, T. M. (1984). Inhibition of lymphocyte proliferation by free fatty acids. I. Differential effects on mouse $\mathrm{B}$ and T lymphocytes. Immunology 53, 235-242.

Calder, P. C. (1995). Fatty acids, dietary lipids and lymphocyte functions. Biochemical Society Transactions 23 , 302-309.

Calder, P. C., Bevan, S. J. \& Newsholme, E. A. (1992). The inhibition of T-lymphocyte proliferation by fatty acids is via an eicosanoid-independent mechanism. Immunology 75, 108-115.

Calder, P. C., Bond, J. A., Bevan, S. J., Hunt, S. V. \& Newsholme, E. A. (1991). Effect of fatty acids on the proliferation of concanavalin A-stimulated rat lymph node lymphocytes. International Journal of Biochemistry 23, 579-588.

Calder, P. C., Bond, J. A., Harvey, D. J., Gordon, S. \& Newsholme, E. A. (1990b). Uptake of saturated and unsaturated fatty acids into macrophage lipids and their effect upon macrophage adhesion and phagocytosis. Biochemical Journal 269, 807-814.

Calder, P. C., Bond, J. A. \& Newsholme, E. A. (1990a). Fatty acid inhibition of lipopolysaccharide-stimulated B lymphocyte proliferation. Biochemical Society Transactions 18, 904-905.

Calder, P. C., Costa-Rosa, L. F. B. P. \& Curi, R. (1995). Effects of feeding lipids of different fatty acid compositions upon rat lymphocyte proliferation. Life Sciences $\mathbf{5 6}, 455-463$.

Calder, P. C. \& Newsholme, E. A. (1992a). Unsaturated fatty acids suppress interleukin-2 production and transferrin receptor expression by concanavalin A-stimulated rat lymphocytes. Mediators of Inflammation 1, 107-115.

Calder, P. C. \& Newsholme, E. A. (1992b). Polyunsaturated fatty acids suppress human peripheral blood lymphocyte proliferation and interleukin-2 production. Clinical Science 82, 695-700.

Calder, P. C. \& Newsholme, E. A. (1993). Influence of antioxidant vitamins on fatty acid inhibition of lymphocyte proliferation. Biochemistry and Molecular Biology International 29, 175-183.

Calder, P. C., Yaqoob, P., Harvey, D. J., Watts, A. \& Newsholme, E. A. (1994a). Incorporation of fatty acids by concanavalin A-stimulated lymphocytes and the effect on fatty acid composition and membrane fluidity. Biochemical Journal 300, 509-518.

Calder, P. C., Yaqoob, P. \& Newsholme, E. A. (1994b). Triacylglycerol metabolism by lymphocytes and the effect of triacylglycerols on lymphocyte proliferation. Biochemical Journal 298, 605-61.1.

Cathcart, E. S., Leslie, C. A., Meydani, S. N. \& Hayes, K. C. (1987). A fish oil diet retards experimental amyloidosis, modulates lymphocyte function and decreases macrophage arachidonate metabolism in mice. Journal of Immunology 139, 1850-1854.

Chang, H. R., Arsenijevic, D., Pechere, J. C., Piguet, P. F., Mensi, N., Girardier, L. \& Dulloo, A. G. (1992). Dietary supplementation with fish oil enhances in vivo synthesis of tumor necrosis factor. Immunology Letters 34, 13-18.

de Deckere, E. A. M., Verplanck, C. J., Blonk, C. G. \& Van Nielen, W. G. L. (1988). Effects of type and amount of dietary fat on rabbit and rat lymphocyte proliferation in vitro. Journal of Nutrition 118, 11-18.

Endres, S., Ghorbani, R., Kelley, V. E., Georgilis, K., Lonnemann, G., van der Meer, J. M. W., Cannon, J. G., Rogers, T. S., Klempner, M. S., Weber, P. C., Schaeffer, E. J., Wolff, S. M. \& Dinarello, C. A. (1989). The effect of dietary supplementation with $n-3$ polyunsaturated fatty acids on the synthesis of interleukin-1 and tumor necrosis factor by mononuclear cells. New England Journal of Medicine 320, 265-271.

Endres, S., Meydani, S. N., Ghorbani, R., Schindler, R. \& Dinarello, C. A. (1993). Dietary supplementation with $n-3$ fatty acids suppresses interleukin-2 production and mononuclear cell proliferation. Journal of Leukocyte Biology 54, 599-603. 
Erickson, K. L. (1984). Dietary fat influences on murine melanoma growth and lymphocyte mediated cytotoxicity. Journal of the National Cancer Institute 72, 115-120.

Erickson, K. L., McNeill, C. J., Gershwin, M. E. \& Ossmann, J. B. (1980). Influence of dietary fat concentration and saturation on immune ontogeny in mice. Journal of Nutrition 110, 1555-1572.

Erickson, K. L. \& Schumacher, L. A. (1989). Lack of an influence of dietary fat on murine natural killer cell activity. Journal of Nutrition 119, 1311-1317.

Ferraris, V. A., DuRubertis, F. R., Hudson, T. H. \& Wolfe, L. (1974). Release of prostaglandins by mitogen and antigen-stimulated leukocytes in culture. Journal of Clinical Investigation 54, 378-386.

Ferreri, N. R., Howland, W. C. \& Speilberg, H. A. S. (1986). Release of leukotrienes $\mathrm{C}_{4}$ and $\mathrm{B}_{4}$ and prostaglandin $E_{2}$ from human monocytes stimulated with aggregated IgG, IgA, IgE. Journal of Immunology 136, 4188-4192.

Friend, J. V., Lock, S. O., Gurr, M. I. \& Parish, W. E. (1980). Effect of different dietary lipids on the immune responses of Hartley strain guinea pigs. International Archives of Allergy and Applied Immunology 62, $292-301$.

Fritsche, K. L. \& Cassity, N. A. (1992). Dietary n-3 fatty acids reduce antibody-dependent cell cytotoxicity and alter eicosanoid release by chicken immune cells. Poultry Science 71, 1646-1657.

Fritsche, K. L., Cassity, N. A. \& Huang, S.-C. (1991). Effect of dietary fat source on antibody production and lymphocyte proliferation in chickens. Poultry Science 70, 611-617.

Fritsche, K. L. \& Johnston, P. V. (1989). Modulation of eicosanoid production and cell-mediated cytotoxicity by dietary alpha-linolenic acid in BALB/c mice. Lipids 24, 305-311.

Fritsche, K. L. \& Johnston, P. V. (1990). Effect of dietary omega-3 fatty acids on cell-mediated cytotoxic activity in BALB/c mice. Nutrition Research 10, 577-588.

Gill, R. \& Clark, W. (1980). Membrane structure-function relationships in cell-mediated cytolysis. Journal of Immunology 125, 689-695.

Goetzl, E. J. (1981). Selective feedback inhibition of the 5-lipoxygenation of arachidonic acid in human T-lymphocytes. Biochemical and Biophysical Research Communications 101, 344-350.

Goldyne, M. E. (1988). Lymphocytes and arachidonic acid metabolism. Progress in Allergy 44, 140-152.

Goldyne, M. E., Burrish, G. F., Poubelle, P. \& Borgeat, P. (1984). Arachidonic acid metabolism among human mononuclear leukocytes: lipoxygenase-related pathways. Journal of Biological Chemistry 259, 8815-8819.

Goldyne, M. E. \& Seaman, W. (1987). Stimulated T cell and natural killer cell lines fail to synthesize leukotriene B. Clinical Research 35, 424A.

Goldyne, M. E. \& Stobo, J. D. (1981). Immunoregulatory role of prostaglandins and related lipids. Critical Reviews in Immunology 2, 189-223.

Goldyne, M. E. \& Stobo, J. D. (1982). Human monocytes synthesise eicosanoids from T lymphocyte-derived arachidonic acid. Prostaglandins 24, 623-630.

Goodwin, J. S. \& Cueppens, J. (1983). Regulation of the immune response by prostaglandins. Journal of Clinical Immunology 3, 295-315.

Hardardottir, I. \& Kinsella, J. E. (1991). Tumour necrosis factor production by murine resident peritoneal macrophages is enhanced by dietary $n-3$ polyunsaturated fatty acids. Biochimica et Biophysica Acta 1095, 187-195.

Hardardottir, I. \& Kinsella, J. E. (1992). Increasing the dietary ( $n-3)$ to $(n-6)$ polyunsaturated fatty acid ratio increases tumor necrosis factor production by murine resident peritoneal macrophages without an effect on elicited peritoneal macrophages. Journal of Nutrition 122, 1942-1951.

Hebert, J. R., Barone, J., Reddy, M. M. \& Backlund, J. Y. (1990). Natural killer cell activity in a longitudinal dietary fat intervention trial. Clinical Immunology and Immunopathology 54, 103-116.

Homan van der Heide, J. J., Bilo, H. J. G., Donker, J. M., Wilmink, J. M. \& Tegzess, A. M. (1993). Effect of dietary fish oil on renal function and rejection in cyclosporine-treated recipients of renal transplants. New England Journal of Medicine 329, 769-773.

Hwang, D. (1989). Essential fatty acids and the immune response. FASEB Journal 3, 2052-2061.

Kelley, D. S., Branch, L. B. \& Iacono, J. M. (1989). Nutritional modulation of human immune status. Nutrition Research 9, 965-975.

Kelley, D. S., Dougherty, R. M., Branch, L. B., Taylor, P. C. \& Iacono, J. M. (1992). Concentration of dietary n-6 polyunsaturated fatty acids and human immune status. Clinical Immunology and Immunopathology 62, 240-244.

Kelley, D. S., Nelson, G. J., Serrato, C. M., Schmidt, P. C. \& Branch, L. B. (1988). Effects of type of dietary fat on indices of immune status of rabbits. Journal of Nutrition 118, 1376-1384. 
Kelly, J. P. \& Parker, C. W. (1979). Effect of arachidonic acid and other unsaturated fatty acids on mitogenesis in human lymphocytes. Journal of Immunology 122, 1556-1562.

Kennedy, M. S., Stobo, J. D. \& Goldyne, M. E. (1980). In vitro synthesis of prostaglandins and related lipids by populations of human peripheral blood mononuclear cells. Prostaglandins 20, 135-145.

Kollmorgen, G. M., Sansing, W. A., Lehman, A. A., Fischer, G., Langley, R. E., Alexander, S. S., King, M. M. \& McCay, P. B. (1979). Inhibition of lymphocyte function in rats fed high fat diets. Cancer Research 39, 3458-3642.

Kramer, T. R., Briske-Anderson, M., Johnson, S. B. \& Holman, R. T. (1986). Influences of dietary polyunsaturated or saturated fatty acids and of concanavalin $A$ upon proliferation of spleen lymphoid cells from rats. Nutrition Research 6, 1219-1227.

Kremer, J. M., Lawrence, D. A., Jubiz, W., Di Giacomo, R., Rynes, K., Bartholomew, L. E. \& Sherman, M. (1990). Dietary fish oil and olive oil supplementation in patients with rheumatoid arthritis. Arthritis and Rheumatism 33, 810-820.

Kumar, G. S., Das, U. N., Kumar, K. V., Madhavi, N., Das, N. P. \& Tan, B. K. H. (1992). Effect of $n-6$ and $n-3$ fatty acids on the proliferation of human lymphocytes and their secretion of TNF-alpha and IL-2 in vitro. Nutrition Research 12,815-823.

Kunkel, S. L., Remick, D. G., Spengler, M. \& Chensue, S. W. (1982). Modulation of macrophage-derived interleukin-1 and tumor necrosis factor by prostaglandin $\mathrm{E}_{2}$. Advances in Prostaglandin, Thromboxane and Leukotriene Research 9, 331-339.

Lands, W. E. M. (1991). Biosynthesis of prostaglandins. Annual Review of Nutrition 11, 41-60.

Lee, T. H., Hoover, R. L., Williams, J. D., Sperling, R. I., Ravalese, J., Spur, B. W., Robinson, D. R., Corey, E. J., Lewis, R. A. \& Austen, K. F. (1985). Effects of dietary enrichment with EPA and DHA on in vitro neutrophil and monocyte leukotriene generation and neutrophil function. New England Journal of Medicine 312, 1217-1224.

Leung, K. H. \& Ip, M. M. (1986). Effect of dietary polyunsaturated fat and 7,12-dimethyl(a)-anthracene on rat splenic natural killer cells and prostaglandin E synthesis. Cancer Immunology and Immunotherapy 21, 161-163.

Levy, J. A., Ibrahim, A. B., Shirai, I., Okta, K., Nagasawa, R., Yoshida, H., Estes, J. \& Gardner, M. (1982). Dietary fat affects immune response, production of antiviral factors and immune complex disease in NZB/NZW mice. Proceedings of the National Academy of Sciences, USA 79, 1974-1978.

Lewis, R. A., Austen, K. F. \& Soberman, R. J. (1990). Leukotrienes and other products of the 5-lipoxygenase pathway. New England Journal of Medicine 323, 645-655.

Locniskar, M., Nauss, K. M. \& Newberne, P. M. (1983). The effect of quality and quantity of dietary fat on the immune system. Journal of Nutrition 113, 951-961.

Lokesh, B. R., Black, J. M., German, J. B. \& Kinsella, J. E. (1988). Docosahexaenoic acid and other dietary omega-3 polyunsaturated fatty acids suppress leukotriene synthesis by mouse peritoneal macrophages. Lipids 23, 968-972.

Lokesh, B. R., Hsieh, H. L. \& Kinsella, J. E. (1986). Peritoneal macrophages from mice fed dietary (n-3) polyunsaturated fatty acids secrete low levels of prostaglandins. Journal of Nutrition 116, 2547-2552.

Lokesh, B. R., Sayers, T. J. \& Kinsella, J. E. (1990). Interleukin-1 and tumor necrosis factor synthesis by mouse peritoneal macrophages is enhanced by dietary $n-3$ polyunsaturated fatty acids. Immunology Letters 23, 281-286.

McIlhinney, R. A. J. (1990). The fats of life: the importance and function of protein acylation. Trends in Biochemical Sciences 15, 387-391.

Magrum, L. J. \& Johnston, P. V. (1983). Modulation of prostaglandin synthesis in rat peritoneal macrophages with $\omega-3$ fatty acids. Lipids $18,514-521$.

Magrum, L. J. \& Johnston, P. V. (1985). Effect of culture in vitro with eicosatetraenoic $(20: 4 n-6)$ and eicosapentaenoic (20:5n-3) acids on fatty acid composition, prostaglandin synthesis and chemiluminescence of rat peritoneal macrophages. Biochimica et Biophysica Acta 836, 354-360.

Marshall, L. A. \& Johnston, P. V. (1985). The influence of dietary essential fatty acids on rat immunocompetent cell prostaglandin synthesis and mitogen-induced blastogenesis. Journal of Nutrition 115, 1572-1580.

Mertin, J. \& Hughes, D. (1975). Specific inhibitory action of polyunsaturated fatty acids on lymphocyte transformation induced by PHA and PPD. International Archives of Allergy and Applied Immunology 48, 203-210.

Mertin, J., Hughes, D. \& Stewart-Wynne, E. (1974). PHA transformation in MS: Inhibition by linoleic acid. Lancet i, 1005-1006. 
Meydani, S. N., Endres, S., Woods, M. M., Goldin, B. R., Soo, C., Morrill-Labrode, A., Dinarello, C. \& Gorbach, S. L. (1991). Oral ( $n-3)$ fatty acid supplementation suppresses cytokine production and lymphocyte proliferation: comparison between young and older women. Journal of Nutrition 121, 547-555.

Meydani, S. N., Lichtenstein, A. H., Cornwall, S., Meydani, M., Goldin, B. R., Rasmussen, H., Dinarello, C. A. \& Schaefer, E. J. (1993). Immunologic effects of national cholesterol education panel step-2 diets with and without fish-derived $n$-3 fatty acid enrichment. Journal of Clinical Investigation 92, 105-113.

Meydani, S. N., Nicolosi, R. J. \& Hayes, K. C. (1985). Effect of long-term feeding of corn oil or coconut oil diets on immune response and prostaglandin $\mathrm{E}_{2}$ synthesis of squirrel and cebus monkeys. Nutrition Research 5, 993-1002.

Meydani, S. N., Yogeeswaran, G., Liu, S., Baskar, S. \& Meydani, M. (1988). Fish oil and tocopherol-induced changes in natural killer cell-mediated cytotoxicity and $\mathrm{PGE}_{2}$ synthesis in young and old mice. Journal of Nutrition 118, 1245-1252.

Mihas, A. A., Gibson, R. G. \& Hirschowitz, B. I. (1975). Suppression of lymphocyte transformation by 16,(16) dimethyl prostaglandin $\mathrm{E}_{2}$ and unsaturated fatty acids. Proceedings of the Society for Experimental Biology and Medicine 149, 1026-1028.

Morrow, W. J. W., Ohashi, Y., Hall, J., Pribnow, J., Hirose, S., Shirai, T. \& Levy, J. A. (1985). Dietary fat and immune function. I. Antibody responses, lymphocyte and accessory cell function in $(\mathrm{NZB} \times \mathrm{NZW}) \mathrm{F} 1$ mice. Journal of Immunology 135, 3857-3863.

Offner, H. \& Clausen, J. (1974). Inhibition of lymphocyte response to stimulants induced by unsaturated fatty acids and prostaglandins in multiple sclerosis. Lancet ii, 1204-1205.

Olson, L. M., Clinton, S. K., Everitt, J. I., Johnston, P. V. \& Visek, W. J. (1987). Lymphocyte activation, cell-mediated cytotoxicity and their relationship to dietary fat-enhanced mammary tumorigenesis in C3H/OUJ mice. Journal of Nutrition 117, 955-963.

Ossman, J. B., Erickson, K. L. \& Cantoly, N. L. (1980). Effects of saturation and concentration of dietary fats on lymphocyte transformation in mice. Nutrition Reports International 22, 279-284.

Parker, C. W. (1987). Lipid mediators produced through the lipoxygenase pathway. Annual Reviews in Immunology 5, 65-84.

Parker, C. W., Stenson, W. F., Huber, M. G. \& Kelley, J. P. (1979). Formation of thromboxane B 2 and hydroxyarachidonic acids in purified human lymphocytes in the presence and absence of PHA. Journal of Immunology 122, 1572-1577.

Pawlowski, N. A., Kaplan, G., Hamill, A. L., Cohn, Z. A. \& Scott, W. A. (1983). Arachidonic acid metabolism by human monocytes. Joumal of Experimental Medicine 158, 393-412.

Poubelle, P. E., Borgeat, P. \& Rola-Pleszczynski, M. (1987). Assessment of leukotriene B $_{4}$ synthesis in human lymphocytes by using high performance liquid chromatography and radioimmunoassay methods. Journal of Immunology 139, 1273-1277.

Rice, C., Hudig, D., Newton, R. S. \& Mendelsohn, J. (1981). Effect of unsaturated fatty acids on human lymphocytes. Disparate influences of oleic and linoleic acids on natural cytotoxicity. Clinical Immunology and Immunopathology 20, 389-401.

Richieri, G. V., Mescher, M. F. \& Kleinfeld, A. M. (1990). Short term exposure to cis unsaturated free fatty acids inhibits degranulation of cytotoxic T lymphocytes. Journal of Immunology 144, 671-677.

Rola-Pleszczynski, M., Gagnon, L. \& Sirois, P. (1983). Leukotriene B $_{4}$ augments human natural cytotoxic cell activity. Biochemical and Biophysical Research Communications 113, 531-537.

Rotondo, D., Earl, C. R. A., Laing, K. J. \& Kaimakamis, D. (1994). Inhibition of cytokine-stimulated thymic lymphocyte proliferation by fatty acids: the role of eicosanoids. Biochimica et Biophysica Acta 1223, $185-194$.

Sanderson, P., Yaqoob, P. \& Calder, P. C. (1995a). Effects of dietary lipid manipulation upon rat spleen lymphocyte functions and the expression of lymphocyte surface molecules. Journal of Nutritional and Environmental Medicine 5, 119-132.

Sanderson, P., Yaqoob, P. \& Calder, P. C. (1995b). Effects of dietary lipid manipulation upon graft vs. host and host vs. graft responses in the rat. Cellular Immunology 164, 240-247.

Santoli, D., Phillips, P. D., Colt, T. L. \& Zurier, R. B. (1990). Suppression of interleukin-2-dependent human $\mathrm{T}$ cell growth in vitro by prostaglandin $\mathrm{E}$ (PGE) and their precursor fatty acids. Journal of Clinical Investigation 85, 424-432.

Sardesi, V. M. (1992). Biochemical and nutritional aspects of eicosanoids. Journal of Nutritional Biochemistry 3, 562-579.

Schmidt, M. F. G. (1989). Fatty acylation of proteins. Biochimica et Biophysica Acta 988, 411-426. 
Sherrington, E. J., Harvey, D. J. \& Calder, P. C. (1995). The effect of dietary lipid manipulation on macrophage phospholipid fatty acid composition and membrane fluidity. Proceedings of the Nutrition Society 54, 121A.

Soyland, E., Nenseter, M. S., Braathen, L. \& Drevon, C. A. (1993). Very long chain $n-3$ and $n-6$ polyunsaturated fatty acids inhibit proliferation of human $\mathrm{T}$ lymphocytes in vitro. European Journal of Clinical Investigation 23, 112-121.

Sperling, R. I., Weinblatt, M. E., Robin, J. L., Ravalese, J., Hoover, R. L., House, F., Coblyn, J. S., Fraser, P. A., Spur, B. W., Robinson, D. R., Lewis, R. A. \& Austen, K. F. (1987). Effects of dietary supplementation with marine fish oil on leukocyte lipid mediator generation and function in rheumatoid arthritis. Arthritis and Rheumatism 30, 987-988.

Stubbs, C. D. \& Smith, A. D. (1984). The modification of mammalian membrane polyunsaturated fatty acid composition in relation to membrane fluidity and function. Biochimica et Biophysica Acta 779, 89-137.

Sumida, C., Graber, R. \& Nunez, E. (1993). Role of fatty acids in signal transduction: modulators and messengers. Prostaglandins, Leukotrienes and Essential Fatty Acids 48, 117-122.

Surette, M. E., Whelan, J., Lu, G., Hardardottir, I. \& Kinsella, J. E. (1995). Dietary $n$-3 polyunsaturated fatty acids modify Syrian hamster platelet and macrophage phospholipid fatty acyl composition and eicosanoid synthesis: a controlled study. Biochimica et Biophysica Acta 122, 185-191.

Tappia, P. S. \& Grimble, R. F. (1994). Complex modulation of cytokine induction by endotoxin and tumour necrosis factor from peritoneal macrophages of rats by diets containing fats of different saturated, monounsaturated and polyunsaturated fatty acid composition. Clinical Science 87, 173-178.

Towler, D. A., Gordon, J. I., Adams, S. P. \& Glaser, L. (1988). The biology and enzymology of eukaryotic protein acylation. Annual Review of Biochemistry 57, $69-99$.

Tsang, W. M., Weyman, C. \& Smith, A. D. (1977). Effect of fatty acid mixtures on phytohaemagglutininstimulated lymphocytes of different species. Biochemical Society Transactions 5, 153-154.

Turek, J. J., Schoenlein, I. A. \& Bottoms, G. D. (1991). The effect of dietary $n-3$ and $n-6$ fatty acids on tumor necrosis factor- $\alpha$ production and leucine aminopeptidase levels in rat peritoneal macrophages. Prostaglandins, Leukotrienes and Essential Fatty Acids 43, 141-149.

Virella, G., Fourspring, K., Hyman, B., Haskill-Stroud, R., Long, L., Virella, I., La Via, M., Gross, A. J. \& Lopes-Virella, M. (1991). Immunosuppressive effects of fish oil in normal human volunteers: Correlation with the in vitro effects of eicosapentaenoic acid on human lymphocytes. Clinical Immunology and Immunopathology 61, 161-176.

Virella, G., Kilpatrick, J. M., Rugeles, M. T., Hyman, B. \& Russell, R. (1989). Depression of humoural responses and phagocytic functions in vivo and in vitro by fish oil and eicosapentaenoic acid. Clinical Immunology and Immunopathology 52, 257-270.

Watanabe, S., Hayashi, H., Onozaki, K. \& Okuyama, H. (1991). Effect of dietary $\alpha$-linolenate/linoleate balance on lipopolysaccharide-induced tumor necrosis factor production in mouse macrophages. Life Sciences 48, 2013-2020.

Watson, J., Madhok, R., Wijelath, E., Capell, H. A., Gillespie, J., Smith, J. \& Byars, B. L. (1990). Mechanism of action of polyunsaturated fatty acids in rheumatoid arthritis. Biochemical Society Transactions 18, 284-285.

Weyman, C., Belin, J., Smith, A. D. \& Thompson, R. H. S. (1975). Linoleic acid as an immunosuppressive agent. Lancet ii, 33 .

Weyman, C., Morgan, S. J., Belin, J. \& Smith, A. D. (1977). Phytohaemmagglutinin stimulation of human lymphocytes: Effect of fatty acids on uridine uptake and phosphoglyceride fatty acid profile. Biochimica et Biophysica Acta 496, 155-166.

Yamashita, N., Maruyama, M., Yamazaki, K., Hamazaki, T. \& Yano, S. (1991). Effect of eicosapentaenoic and docosahexaenoic acid on natural killer cell activity in human peripheral blood lymphocytes. Clinical Immunology and Immunopathology 59, 335-345.

Yamashita, N., Yokoyama, A., Hamazaki, T. \& Yano, S. (1986). Inhibition of natural killer cell activity of human lymphocytes by eicosapentaenoic acid. Biochemical and Biophysical Research Communications 138, 1058-1067.

Yaqoob, P. \& Calder, P. C. (1993). The effects of fatty acids on lymphocyte functions. International Joumal of Biochemistry 25, 1705-1714.

Yaqoob, P. \& Calder, P. C. (1995a). Effects of dietary lipid manipulation upon inflammatory mediator production by murine macrophages. Cellular Immunology 163, 120-128.

Yaqoob, P. \& Calder, P. C. $(1995 b)$. The effects of dietary lipid manipulation on the production of murine T-cell-derived cytokines. Cytokine 7, 548-553. 
Yaqoob, P., Newsholme, E. A. \& Calder, P. C. (1994a). The effect of dietary lipid manipulation on rat lymphocyte subsets and proliferation. Immunology 82, 603-610.

Yaqoob, P., Newsholme, E. A. \& Calder, P. C. (1994b). Inhibition of natural killer cell activity by dietary lipids. Immunology Letters 41, 241-247.

Yaqoob, P., Newsholme, E. A. \& Calder, P. C. (1995). The effect of dietary lipid manipulation on leucocyte proliferation in whole blood. Nutrition Research 15, 279-287.

Yi, F. J., Funk, C. D., Wetterholm, A. \& Radmark, O. (1988). Leukotriene $A_{4}$ conversion to leukotriene $\mathbf{B}_{4}$ in human T-cell lines. Prostaglandins 36, 241-248. 